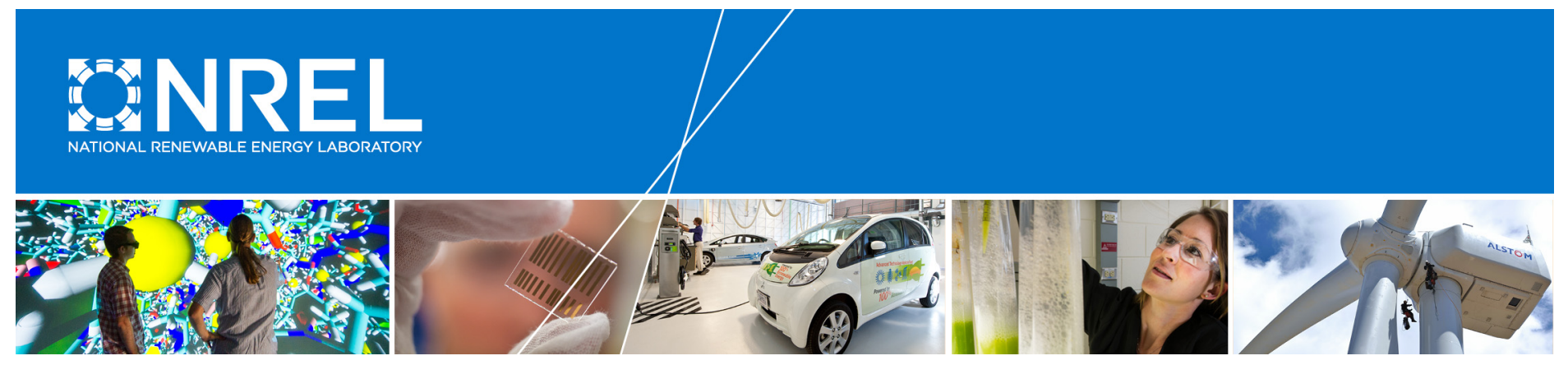

\title{
Hydrogen Fuel Cell Performance as Telecommunications Backup Power in the United States
}

Jennifer Kurtz, Genevieve Saur, and Sam Sprik National Renewable Energy Laboratory

NREL is a national laboratory of the U.S. Department of Energy Office of Energy Efficiency \& Renewable Energy Operated by the Alliance for Sustainable Energy, LLC

This report is available at no cost from the National Renewable Energy Laboratory (NREL) at www.nrel.gov/publications.

Technical Report

NREL/TP-5400-60730

March 2015

Contract No. DE-AC36-08G028308 


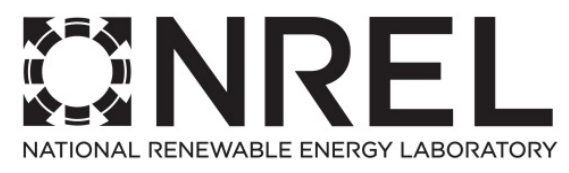

\section{Hydrogen Fuel Cell Performance as Telecommunications Backup Power in the United States}

Jennifer Kurtz, Genevieve Saur, and Sam Sprik National Renewable Energy Laboratory

Prepared under Task No. HT12.8610

NREL is a national laboratory of the U.S. Department of Energy Office of Energy Efficiency \& Renewable Energy Operated by the Alliance for Sustainable Energy, LLC

This report is available at no cost from the National Renewable Energy Laboratory (NREL) at www.nrel.gov/publications.

National Renewable Energy Laboratory 15013 Denver West Parkway Golden, CO 80401 303-275-3000 • www.nrel.gov
Technical Report

NREL/TP-5400-60730

March 2015

Contract No. DE-AC36-08GO28308 


\section{NOTICE}

This report was prepared as an account of work sponsored by an agency of the United States government. Neither the United States government nor any agency thereof, nor any of their employees, makes any warranty, express or implied, or assumes any legal liability or responsibility for the accuracy, completeness, or usefulness of any information, apparatus, product, or process disclosed, or represents that its use would not infringe privately owned rights. Reference herein to any specific commercial product, process, or service by trade name, trademark, manufacturer, or otherwise does not necessarily constitute or imply its endorsement, recommendation, or favoring by the United States government or any agency thereof. The views and opinions of authors expressed herein do not necessarily state or reflect those of the United States government or any agency thereof.

This report is available at no cost from the National Renewable Energy Laboratory (NREL) at www.nrel.gov/publications.

Available electronically at SciTech Connect http:/www.osti.gov/scitech

Available for a processing fee to U.S. Department of Energy and its contractors, in paper, from:

U.S. Department of Energy

Office of Scientific and Technical Information

P.O. Box 62

Oak Ridge, TN 37831-0062

OSTI http://www.osti.gov

Phone: 865.576.8401

Fax: 865.576.5728

Email: reports@osti.gov

Available for sale to the public, in paper, from:

U.S. Department of Commerce

National Technical Information Service

5301 Shawnee Road

Alexandria, VA 22312

NTIS http://www.ntis.gov

Phone: 800.553 .6847 or 703.605 .6000

Fax: 703.605.6900

Email: orders@ntis.gov 


\section{Acknowledgments}

Funding for this report came from the U.S. Department of Energy's Fuel Cell Technologies Office in the Office of Energy Efficiency and Renewable Energy. The authors would like to acknowledge the industry project partners, both developers and end users, for their participation through providing deployment and operation data as well as review of National Renewable Energy Laboratory composite data products. Their participation and review is essential, and appreciated, for the validation analysis summarized in this report. 


\section{List of Acronyms}

ARRA

CHP

DOE

FEMA MOTF

IAA

HSM

$\mathrm{kW}$

MHE

MTBIO

MW

NFCTEC

NREL
American Recovery and Reinvestment Act of 2009 combined heat and power U.S. Department of Energy

Federal Emergency Management Agency Modeling Task Force Interagency Agreement hydrogen storage module kilowatt material handling equipment mean time between interrupted operation megawatt National Fuel Cell Technology Evaluation Center National Renewable Energy Laboratory 


\section{Executive Summary}

Fuel cells can provide emergency backup power during outages as well as decrease the economic and productivity losses during other grid instabilities. Fuel cells provide an extended run time similar to that of diesel generators while also providing a low-emission and low-noise solution, which is especially important in urban environments. Working in collaboration with the U.S. Department of Energy (DOE) and industry project partners, the National Renewable Energy Laboratory (NREL) acts as the central data repository for the data collected from real-world operation of fuel cell backup power systems. NREL aims to perform an independent assessment of the technology's status in real-world operations, establish performance baselines, report on fuel cell and hydrogen technology, and support market growth by evaluating performance relevant to the markets' value proposition.

With American Recovery and Reinvestment Act of 2009 (ARRA) co-funding awarded through DOE's Fuel Cell Technologies Office, more than 1,300 fuel cell units were deployed over a three-plus-year period in stationary, material handling equipment, auxiliary power, and backup power applications. This surpassed a Fuel Cell Technologies Office ARRA objective to spur commercialization of an early market technology by installing 1,000 fuel cell units across several different applications, including backup power.

By December 2013, 852 backup power units out of 1,330 fuel cell units deployed were providing backup service, mainly for telecommunications towers. For 136 of the fuel cell backup units, project participants provided detailed operational data to the National Fuel Cell Technology Evaluation Center (NFCTEC) for analysis by NREL's technology validation team. The NFCTEC analysis focused on deployment, reliability, and operation trends.

The number of fuel cell backup power systems deployed increased more than 19-fold from 44 to 852 from the beginning to the end of the project. Figure ES-1 shows a map of the site locations and key deployment statistics. 


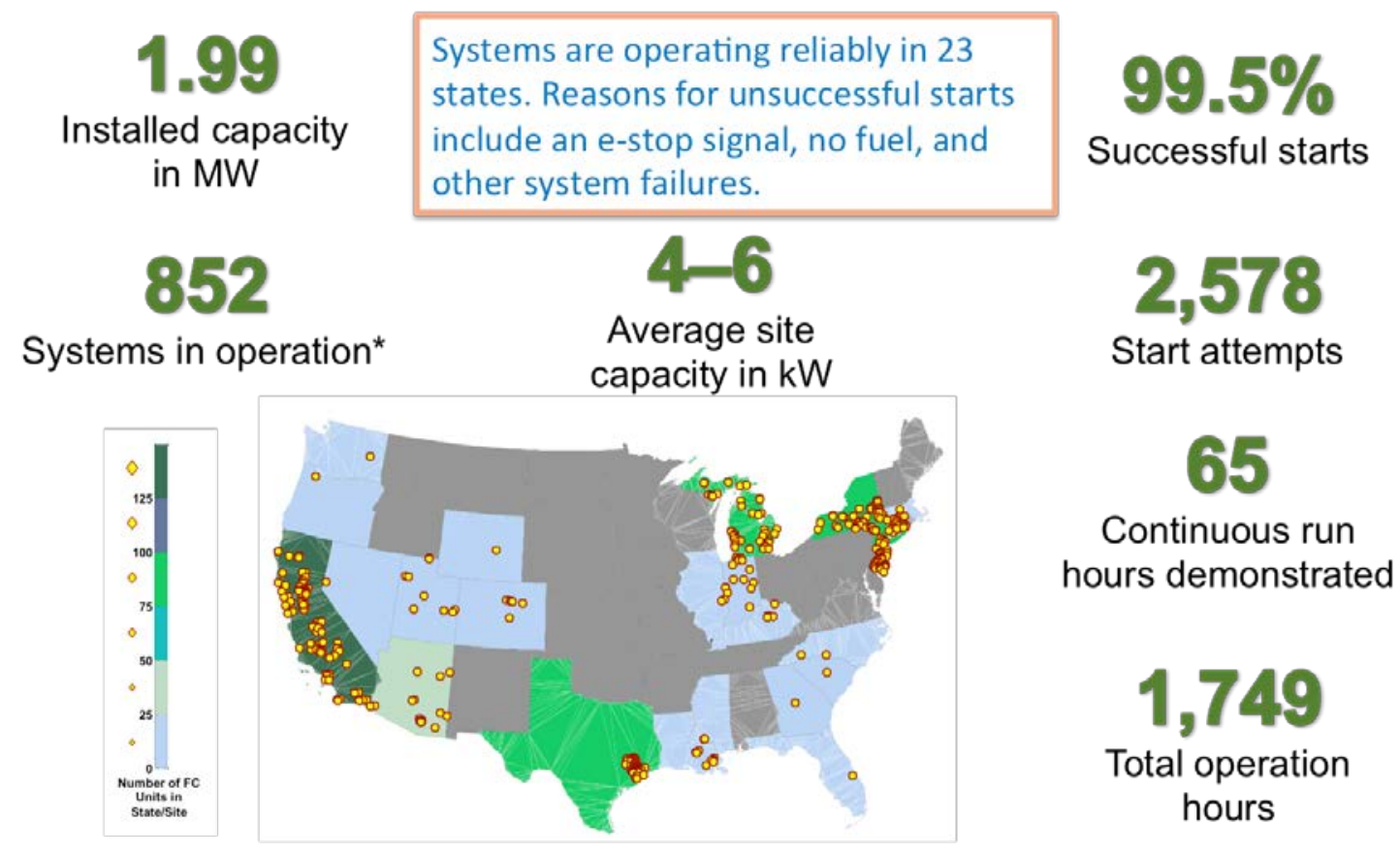

*Not all systems have detailed data reporting to NREL

Figure ES-1. Fuel cell backup power locations and operation summary 2009-2013

Of the analyzed system starts, $40 \%$ were due to site demand (for example a grid outage) and the remaining starts were due to system conditioning. The fuel cells accumulated more than 1,749 hours of operation time. The operation hours requirement for the systems analyzed was typically low. However there were instances when an extended operation was required. One unit successfully demonstrated a continuous run time of 65 hours during the data collection period. The average run time of a start was 42 minutes, and the backup fuel cells were typically started once a month.

The importance of extended run time can be seen more specifically in context with major known events. Looking at grid data from the times of several major hurricanes (Sandy, Irene, and Isaac), the average outage during the hurricanes was almost 87 hours, with a low of 56 hours for Hurricane Irene and a high of 143 hours for Hurricane Sandy (Figure ES-2). The median grid incident duration from the unfiltered data set was 11.7 hours. 


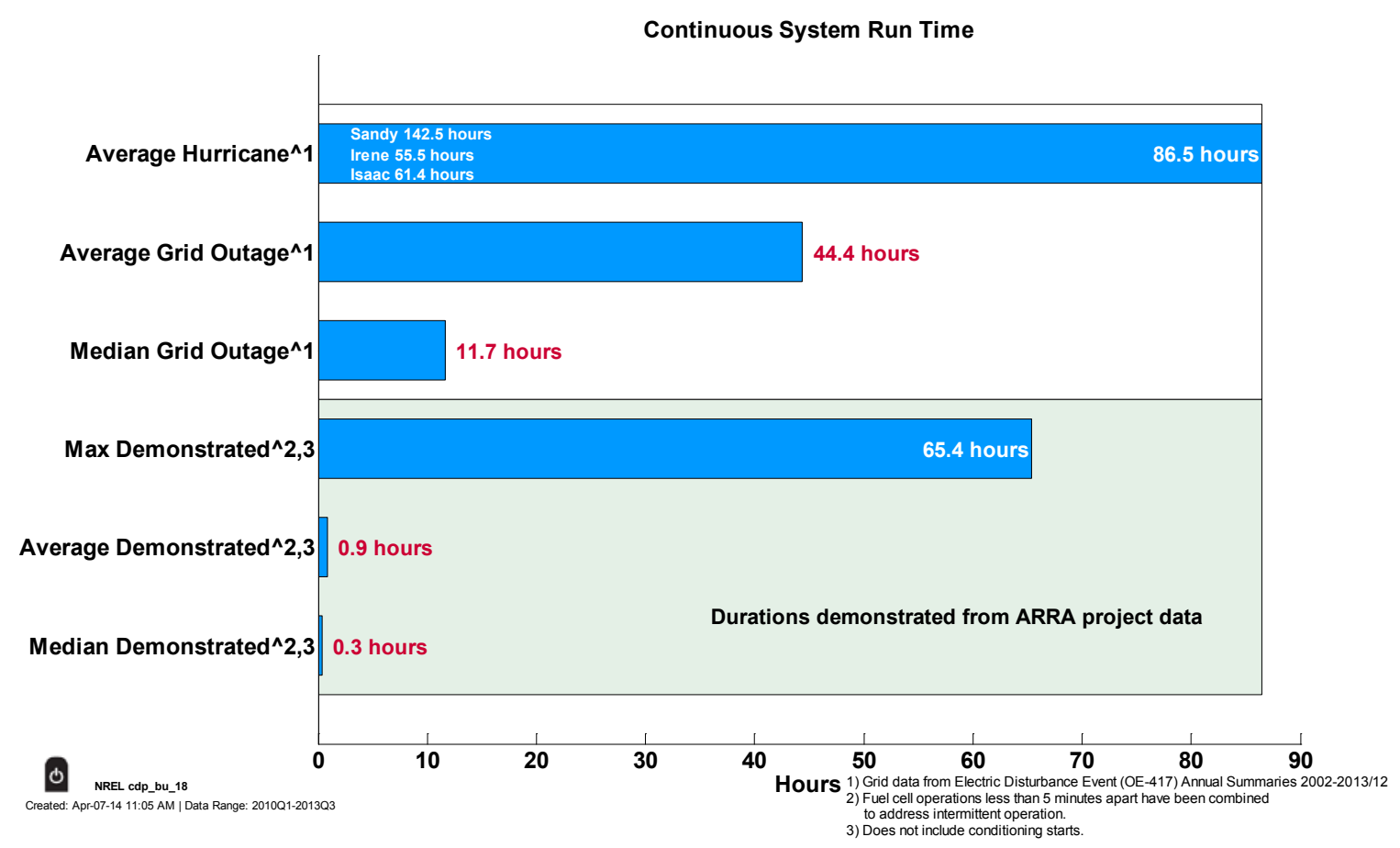

Figure ES-2. Comparison of grid events to fuel cell backup power operation

The start reliability of the analyzed systems was $99.5 \%$. There were only 13 interrupted operations during the 4-year monitoring period. System failure was the major cause of eight unsuccessful starts. These system failures varied in cause; some related to the system and integration with the site. Three of the eight system failures were related to a software error in certain situations, which was subsequently fixed. This real-world situational feedback is a critical product development step for fuel cell system manufacturers.

An additional way to study the backup power system reliability is with mean time between interrupted operation (MTBIO). The MTBIO averages all of the operation periods, in calendar days, based on interrupted operation events. As shown in Figure ES-3, the majority of systems $(94 \%)$ did not experience an interrupted operation during this evaluation period. Of the $6 \%$ of systems that did experience an interrupted operation, the median MTBIO was 465 days. 


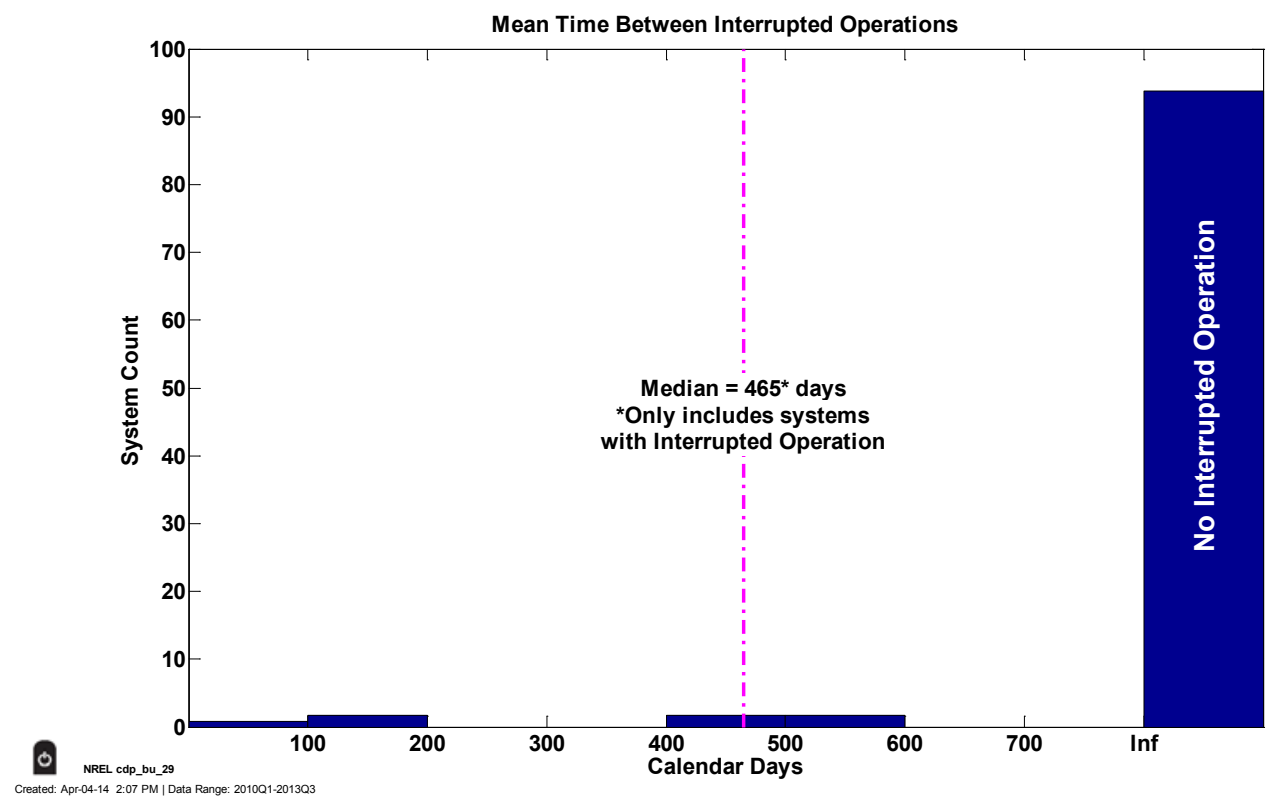

Figure ES-3. Mean time between interrupted operation

An annualized cost of ownership analysis enables a better understanding of the value proposition for fuel cell backup power systems when compared with the incumbent technologies of battery and diesel generator systems. Backup power operation can vary widely based on region, end user, and site-specific requirements, so a number of assumptions are made to compare three different backup power technologies (diesel, battery, and fuel cell) operating in similar circumstances in four run time scenarios $(8,52,72$, and 176 hours). Each run time scenario assumes the system operates for a specific amount of hours annually-for example, a system in the 72-hour scenario operates for 72 hours a year. The 72 hours could be accumulated through many shorter run operations or through one continuous operation. It is important to note that the actual use of a telecommunication system is not as simple, or as prescribed, as these run time scenarios.

This cost of ownership analysis identifies the factors impacting the value proposition for fuel cell backup power and the estimated annualized cost of ownership for three backup power technologies. Figure ES-4 displays the annualized cost estimates for each run time scenario and technology. Cost estimates for capital, permitting and installation, maintenance, and fuel are included for each of the technologies. 


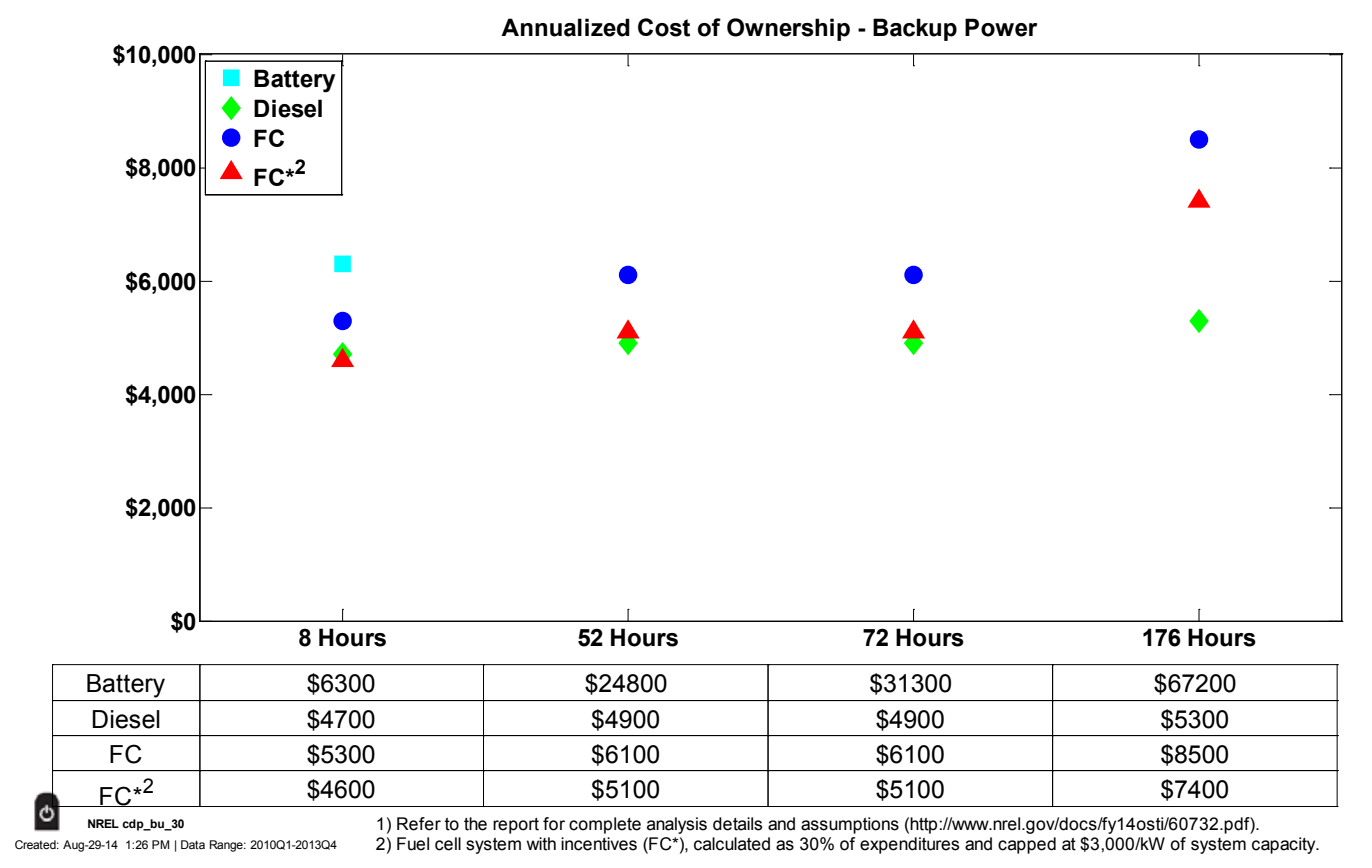

Fuel Cell* includes incentives

Figure ES-4. Annualized cost of ownership for technology and run time scenarios

The fuel cell system with incentives ${ }^{1}$ (denoted $\mathrm{FC}^{*}$ in figures) is cost competitive with the diesel generator, particularly in the 8-hour, 52-hour, and 72-hour run time scenarios. The fuel cell system has a higher efficiency and less frequent maintenance schedule than the diesel generator does, and the incentives offset the higher capital and installation costs. Refer to an NFCTEC report (Kurtz et al. 2014) for a detailed breakdown of cost, assumptions, and results. Cost wise, the initial capital investment is higher for fuel cells, even with federal and state incentives, but fuel cell backup power systems provide benefits that battery and battery-diesel generators do not in areas such as operation and maintenance cost. Better system integration, easier siting and permitting, and developed infrastructure for hydrogen and maintenance can reduce the economic gap between fuel cells and other backup power technologies.

\footnotetext{
1 "The credit is equal to $30 \%$ of expenditures, with no maximum credit. However, the credit for fuel cells is capped at $\$ 1,500$ per 0.5 kilowatt $(\mathrm{kW})$ of capacity. Eligible property includes fuel cells with a minimum capacity of $0.5 \mathrm{~kW}$ that have an electricity-only generation efficiency of 30\% or higher." (DSIRE 2014a)
} 


\section{Table of Contents}

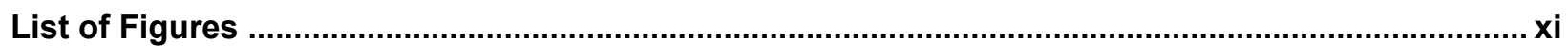

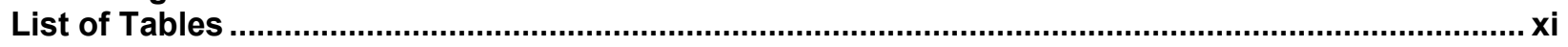

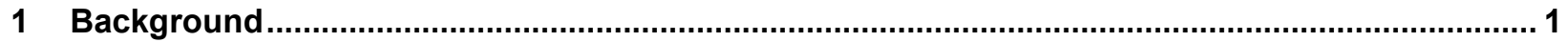

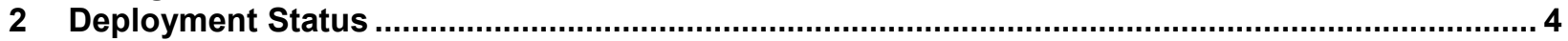

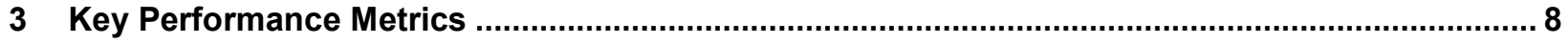

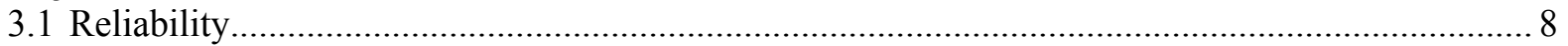

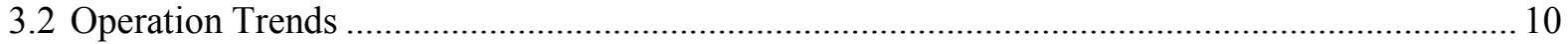

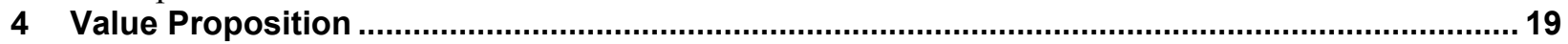

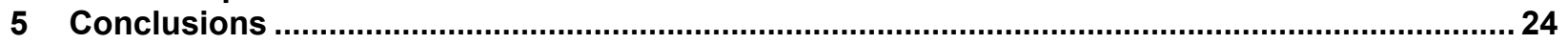

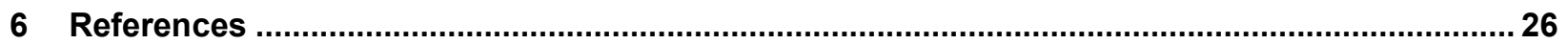

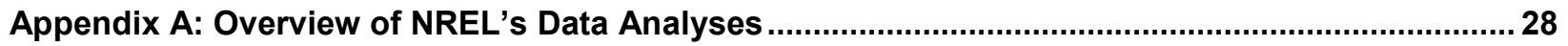

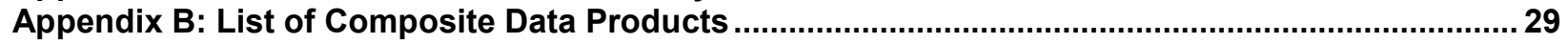




\section{List of Figures}

Figure ES-1. Fuel cell backup power locations and operation summary 2009-2013 ........................vi

Figure ES-2. Comparison of grid events to fuel cell backup power operation ................................... vii

Figure ES-3. Mean time between interrupted operation .................................................................... viii

Figure ES-4. Annualized cost of ownership for technology and run time scenarios ......................... ix

Figure 1. Early market fuel cell deployments funded through ARRA .............................................. 2

Figure 2. Timeline of ARRA and IAA fuel cell backup power deployments ....................................... 4

Figure 3. Timeline of ARRA and IAA fuel cell backup power installed capacity................................ 5

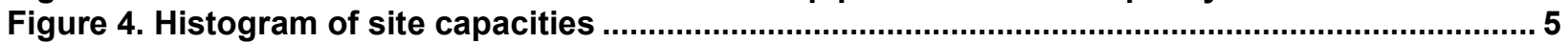

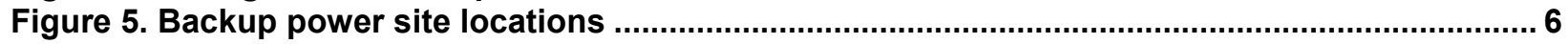

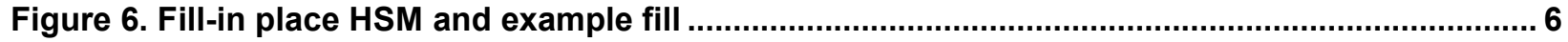

Figure 7. Example ReliOn fuel cell system with replaceable cylinders and an HSM ........................ 7

Figure 8. Number of starts by fuel cell backup power units during the analysis period .................... 8

Figure 9. Start reliability of deployed fuel cell backup power units ................................................. 9

Figure 10. Mean time between interrupted operation .................................................................... 10

Figure 11. Operation hours per month by fuel cell backup power units deployed............................11

Figure 12. Histogram of total operation hours by fuel cell backup power units deployed ............... 12

Figure 13. Time between starts with identification of conditioning starts....................................... 12

Figure 14. Starts by time of day with identification of conditioning starts .................................... 13

Figure 15. Continuous run time of fuel cell backup units............................................................. 14

Figure 16. Histogram of average number of starts per month per system ....................................... 14

Figure 17. Histogram of average run time per month per system .............................................. 15

Figure 18. Number and average time of grid outages 2002-2013 from Electric Disturbance Event

Annual Summaries

Figure 19. Snapshot of the fuel cell backup power animated visualization map .............................. 16

Figure 20. Ambient temperature at start-up of backup power fuel cell units .................................. 17

Figure 21. Comparison of grid events to fuel cell backup power operation...................................... 18

Figure 22. ARRA backup power site locations in FEMA MOTF impact area for Hurricane Sandy... 18

Figure 23. Annualized cost of ownership technology comparison for multiple run time scenarios

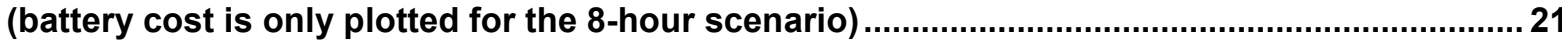

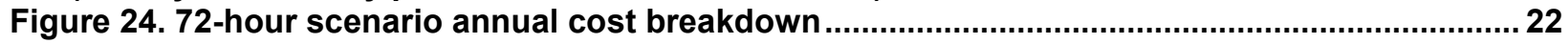

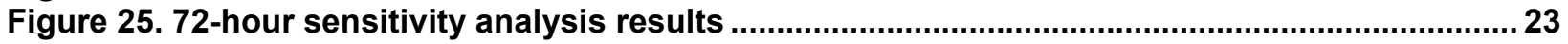

Figure A-1. NREL's aggregated data analysis using the NFCTEC ................................................. 28

Figure B-1. Fuel cell backup power CDPs by analysis category and number................................. 29

\section{List of Tables}

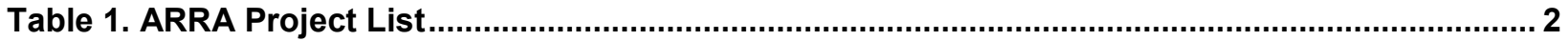

Table 2. Qualitative Comparison of Backup Power Technologies..................................................... 19

Table 3. Fuel Cell Backup Power Performance Status Summary …................................................ 25 


\section{Background}

Commercial growth of the wireless telecommunications market in the United States and overseas provides opportunities for domestic and international sales of backup power fuel cells. Telecommunications backup power expenditures are estimated at more than $\$ 2$ billion annually (Colbow 2010). Deployment of fuel cell systems is a practical option for telecommunications operations that need reliable, long-running backup power at cellular phone signal relay sites, particularly during electric grid power outages.

Reliability, availability, and cost are critical metrics for a backup power application. A backup power application is a prime early market for fuel cells because fuel cells can operate comparably (for example power and reliability) to incumbent technologies such as batteries and diesel generators and can combine positive operation features from both of those incumbent technologies in one system. With a hydrogen supply, a fuel cell can operate for an extended period of time like a generator while operating cleanly, efficiently, reliably, and quietly like a battery. Fuel cells for backup power can be installed and operated at new or retrofit sites in different regions.

Over approximately a two-year period, 1,330 fuel cell units (Figure 1) were deployed in stationary, material handling equipment, auxiliary power, and backup power applications with American Recovery and Reinvestment Act of 2009 (ARRA) co-funding awarded through the U.S. Department of Energy's (DOE's) Fuel Cell Technologies Office. This surpassed a Fuel Cell Technologies Office objective of deploying up to 1,000 fuel cell units using ARRA funding.

DOE's Fuel Cell Technologies Office awarded 12 projects with approximately $\$ 40$ million in ARRA funding and approximately $\$ 53$ million in industry cost share; of this total, $\$ 18.5$ million in ARRA funding went to three backup power projects (DOE 2014a). The prime backup power ARRA awards were to Sprint-Nextel and ReliOn, ${ }^{2}$ with a small number of demonstrations awarded to Plug Power. Other project partners included technology developers and end users: PG\&E, AT\&T, Robins Air Force Base, Fort Irwin, IdaTech (recently acquired by Ballard), Altergy, Air Products and Chemicals, Inc., Champion Energy, Ericsson Services, Inc., A\&E Firms, Black \& Veatch, and Burns \& McDonnell.

As of December 2013, 852 ARRA-funded fuel cell units were deployed in backup power applications in both urban and rural areas. These ARRA co-funded fuel cell deployments supported hydrogen fuel cell commercialization through an accelerated deployment, impacting many areas of the market including manufacturing, permitting, installation, hydrogen infrastructure, operation, maintenance, and support services.

\footnotetext{
${ }^{2}$ ReliOn was acquired by Plug Power as of April 2014, just before publication of this report. The brand name is being retained by Plug Power and will be used throughout this report.
} 


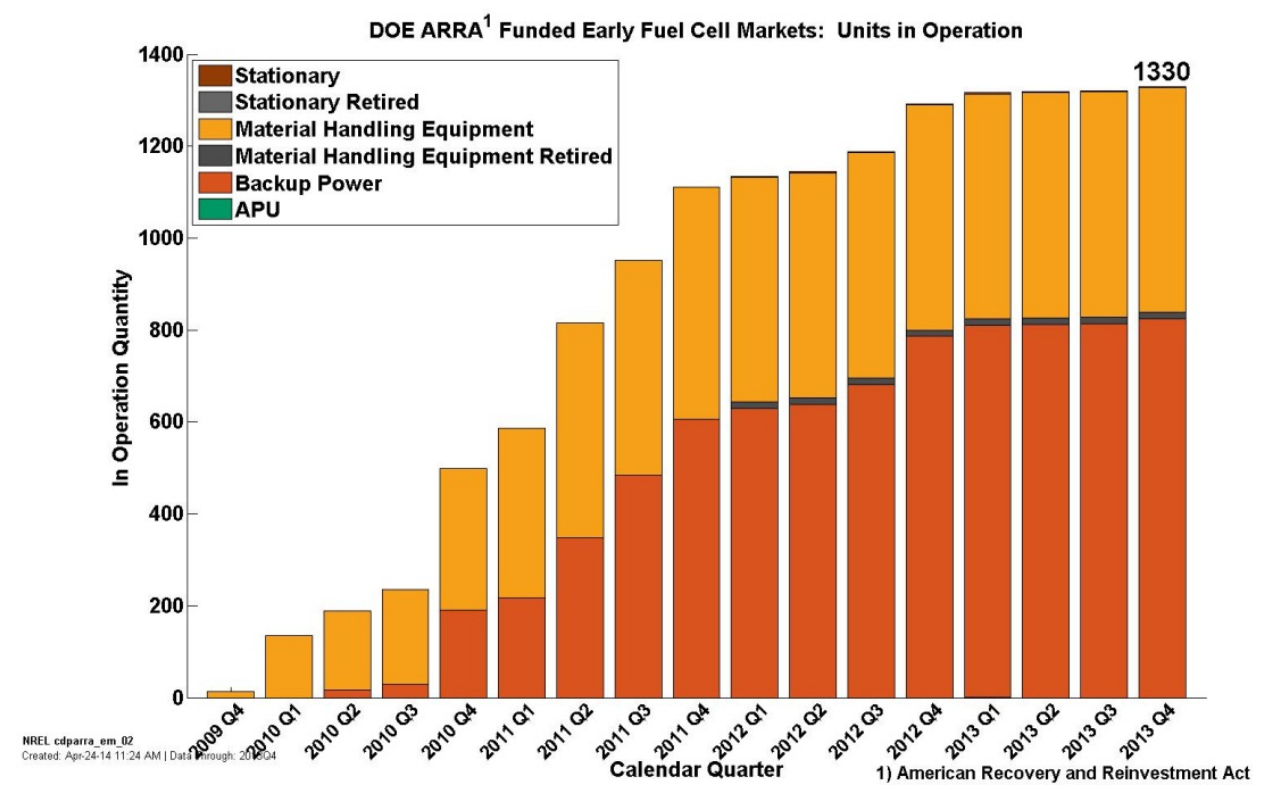

Figure 1. Early market fuel cell deployments funded through ARRA

Table 1 lists the project, application, and deployment details. Individual project details can be found at the U.S. Department of Energy's (DOE's) Annual Merit Review website for the years 2010 through 2012 (DOE 2014b).

Table 1. ARRA Project List

\begin{tabular}{|c|c|c|c|c|}
\hline Company & Award & Application & Deployment & Status \\
\hline Delphi Automotive & $\$ 2.4 \mathrm{M}$ & $\begin{array}{l}\text { Auxiliary } \\
\text { power }\end{array}$ & 1 unit & In progress \\
\hline FedEx Freight East ${ }^{3}$ & $\$ 1.3 \mathrm{M}$ & $\begin{array}{l}\text { Specialty } \\
\text { vehicle }\end{array}$ & 1 site; 35 MHE units; 2 dispensers & In progress \\
\hline GENCO & $\$ 6.1 \mathrm{M}$ & $\begin{array}{l}\text { Specialty } \\
\text { vehicle }\end{array}$ & 5 sites; 35 MHE units; >5 dispensers & In progress \\
\hline Jadoo Power & $\$ 2.2 \mathrm{M}$ & $\begin{array}{l}\text { Backup } \\
\text { power }\end{array}$ & 1 unit & \\
\hline MTI MicroFuel Cells & $\$ 3.0 \mathrm{M}$ & Portable & NA & Completed \\
\hline Nuvera Fuel Cells & $\$ 1.1 \mathrm{M}$ & $\begin{array}{l}\text { Specialty } \\
\text { vehicle }\end{array}$ & 1 site; 14 MHE units; 2 dispensers & Completed \\
\hline Plug Power, Inc. (1) & $\$ 3.4 \mathrm{M}$ & $\mathrm{CHP}$ & 2 sites; 2 systems & In progress \\
\hline Plug Power, Inc. (2) & $\$ 2.7 \mathrm{M}$ & $\begin{array}{l}\text { Backup } \\
\text { power }\end{array}$ & 2 sites; 20 systems & In progress \\
\hline Univ. of N. Florida & $\$ 2.5 \mathrm{M}$ & Portable & NA & Completed \\
\hline
\end{tabular}

\footnotetext{
${ }^{3}$ FedEx added five more fuel cell MHE units at this site with no additional DOE funding. See http://www.hydrogen.energy.gov/pdfs/review12/h2ra009_king_2012_o.pdf.
} 


\begin{tabular}{|c|c|c|c|c|}
\hline Company & Award & Application & Deployment & Status \\
\hline ReliOn Inc. & $\$ 8.5 \mathrm{M}$ & $\begin{array}{l}\text { Backup } \\
\text { power }\end{array}$ & $\begin{array}{l}189 \text { sites (end users include AT\&T and } \\
\text { PG\&E) }\end{array}$ & Completed \\
\hline Sprint Comm. & $\$ 7.3 \mathrm{M}$ & $\begin{array}{l}\text { Backup } \\
\text { power }\end{array}$ & 260 sites (with ReliOn and Altergy) & In progress \\
\hline Sysco of Houston & $\$ 1.2 \mathrm{M}$ & $\begin{array}{l}\text { Specialty } \\
\text { vehicle }\end{array}$ & 1 site; 98 MHE; 2 dispensers & In progress \\
\hline
\end{tabular}

$\mathrm{CHP}=$ combined heat and power

$\mathrm{MHE}=$ material handling equipment

DOE's Hydrogen Safety Panel participated in ARRA through safety plan reviews and safety evaluation site visits. The panel provided feedback to project partners with a detailed report identifying review comments, recommendations, follow-ups, and conclusions (Barilo 2013). This panel participation leverages hydrogen experts to ensure proper and necessary safety planning and practices.

To support the validation and market transformation objectives of the project, the project participants collected and submitted data to the National Fuel Cell Technology Evaluation Center (NFCTEC) at the National Renewable Energy Laboratory (NREL). NREL's objective is to validate hydrogen polymer electrolyte membrane fuel cells used in early market applications as well as their related infrastructure. Building on its experience with the technology validation of hydrogen fuel cell vehicles and fueling infrastructure, NREL has been performing technical analyses of hydrogen and fuel cell systems for DOE's Fuel Cell Technologies Office to assess the performance and market potential of fuel cell technologies. While individual company data are kept confidential, NREL publishes aggregated performance analysis results called "composite data products" (CDPs) that show the status and performance of hydrogen and fuel cell technologies without identifying individual companies or their performance. This technology validation includes identifying the current status of the technology and its evolution over the duration of the project, assisting DOE's hydrogen research and development activities based on information learned from the project, and helping industry in evaluating progress toward technology readiness. See Appendix A for more details on NREL's data analyses.

In addition to the ARRA co-funded fuel cell backup power demonstrations, DOE supported additional demonstration projects with other federal agencies through Interagency Agreements (IAA). The Department of Defense and the Federal Aviation Administration are two agencies with fuel cell backup power demonstrations that also submitted operational and deployment data to NREL. All results covered in this report, unless specified as strictly ARRA, will include both ARRA and IAA fuel cell backup power sites. Almost all sites ( 98\%) were co-funded through ARRA.

NREL analyzed operational data collected from these government co-funded demonstration projects to characterize key fuel cell backup power performance metrics, including reliability and operation trends, and to highlight the business case for using fuel cells in these early market applications. NREL's analyses include these critical metrics, along with deployment, U.S. grid outage statistics, and infrastructure operation. All results from this analysis project, including any other publications and presentations, are available online (NREL 2013a). 


\section{Deployment Status}

As of the end of 2013, 852 fuel cell backup power units were deployed in the field in 23 states. Figure 2 shows a timeline of cumulative systems deployed from 2009 to 2013. In just three years, the number of units tracked by NREL went from 44 to 852, a more than 19-fold increase. Deployments were primarily focused on using fuel cells as a backup power source for telecommunication towers, and approximately $98 \%$ of the deployments were co-funded through ARRA. Most of these sites did not have extended run time backup power capability until the fuel cell systems were in operation.

Deployment hurdles observed by NREL included the long time required and the difficulty in acquiring and permitting a site, which tends to be the longest segment for installing hydrogen fuel cells. Some of the challenge is created by the variety of sites and also because of the use of hydrogen. While site acquisition and permitting remain hurdles, NREL has seen a significant increase in deployments in three years and therefore increased understanding of the systems, especially in jurisdictions with previous hydrogen fuel cell experience.

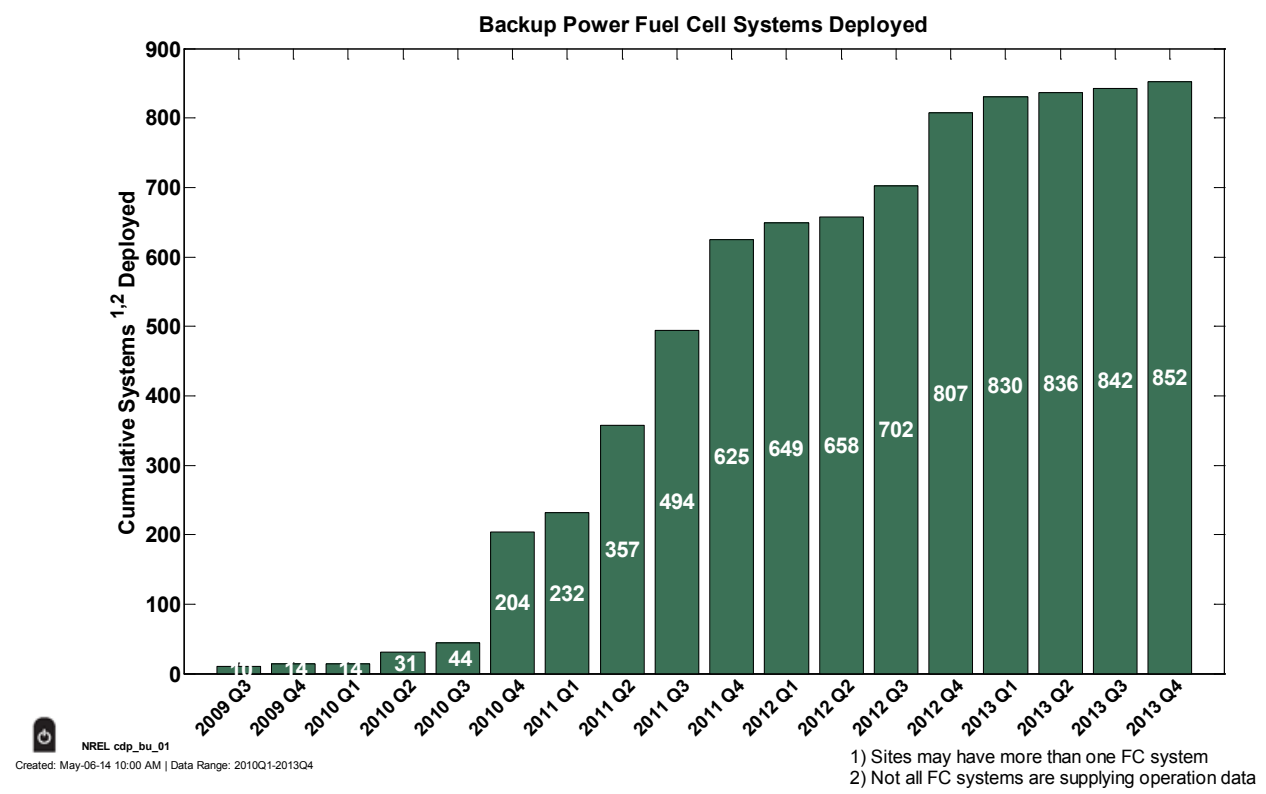

Figure 2. Timeline of ARRA and IAA fuel cell backup power deployments

The scheduled deployments are now complete for the ARRA projects. The installed capacity followed the same trend as the number of units deployed, jumping from 130 kilowatts $(\mathrm{kW})$ at the end of the third quarter in 2010 to 1.99 megawatts (MW) at the end of 2013 (Figure 3). The backup power fuel cell systems are modular in that each unit can be a building block for a total system capable of meeting the power needs for each individual site. For instance, Altergy and ReliOn units in the ARRA project ranged in size from $2 \mathrm{~kW}$ to $5 \mathrm{~kW}$. Units can be combined together for higher power at a location if needed. 


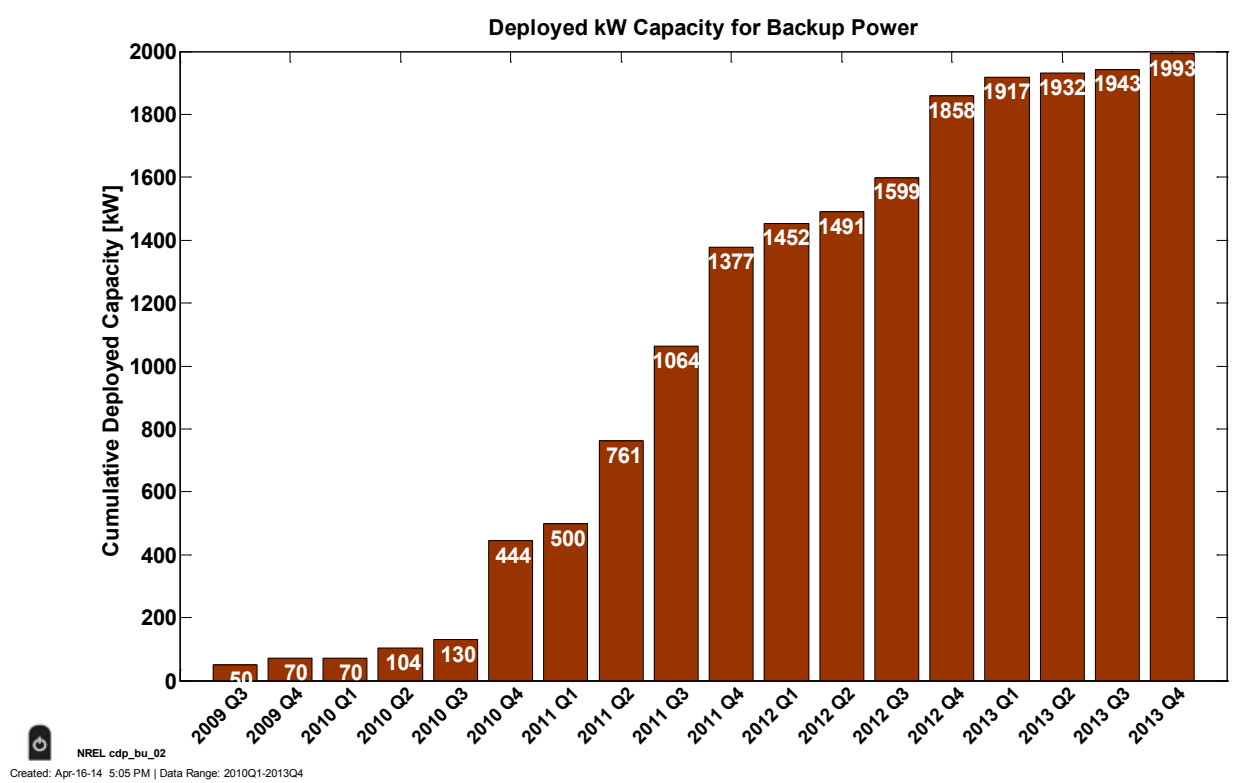

Figure 3. Timeline of ARRA and IAA fuel cell backup power installed capacity

The majority of sites (78\%) tracked by NREL had capacities of 4-6 kW (Figure 4). There were a few sites with higher capacity, as can be seen in the stem plot of deployed sites (Figure 5). This map identifies the site capacity (height of orange bar) and the concentration in a state by color. For instance, California had the highest number of systems installed. The high concentrations of sites in California and the Northeast are primarily due to the location of project partners and population. Other site location factors include impact, regulations, use, and grid stability.

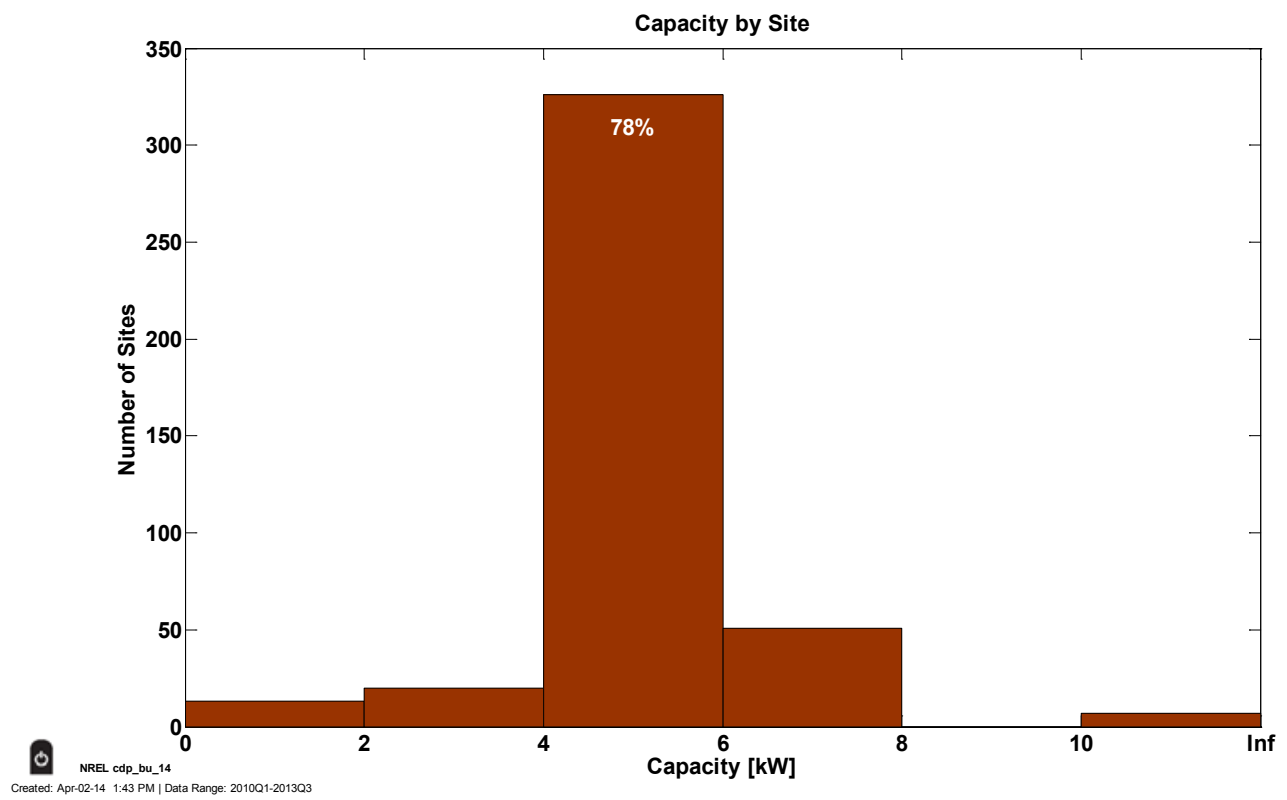

Figure 4. Histogram of site capacities 


\begin{tabular}{c|c|c|}
\hline State & $\mathrm{kW}$ & Sites \\
\hline Arizona & 84 & 19 \\
\hline California & 635 & 130 \\
\hline Colorado & 25 & 6 \\
\hline Connecticut & 130 & 28 \\
\hline Florida & 6 & 1 \\
\hline Georgia & 50 & 1 \\
\hline Illinois & 4 & 2 \\
\hline Indiana & 50 & 16 \\
\hline Kentucky & 22 & 4 \\
\hline Louisiana & 40 & 8 \\
\hline Massachusetts & 10 & 1 \\
\hline Michigan & 168 & 41 \\
\hline Mississippi & 10 & 2 \\
\hline Nevada & 2 & 1 \\
\hline New Jersey & 181 & 40 \\
\hline New York & 238 & 55 \\
\hline North Carolina & 10 & 2 \\
\hline Oregon & 2 & 1 \\
\hline South Carolina & 50 & 1 \\
\hline Texas & 238 & 48 \\
\hline Utah & 36 & 9 \\
\hline Washington & 1 & 1 \\
\hline Wyoming & 2 & 1 \\
\hline \multicolumn{2}{|c}{}
\end{tabular}

\begin{tabular}{l|l|l|} 
Totals & 1993 & 418 \\
\hline
\end{tabular}

NREL cdp_bu_Bos

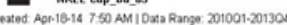

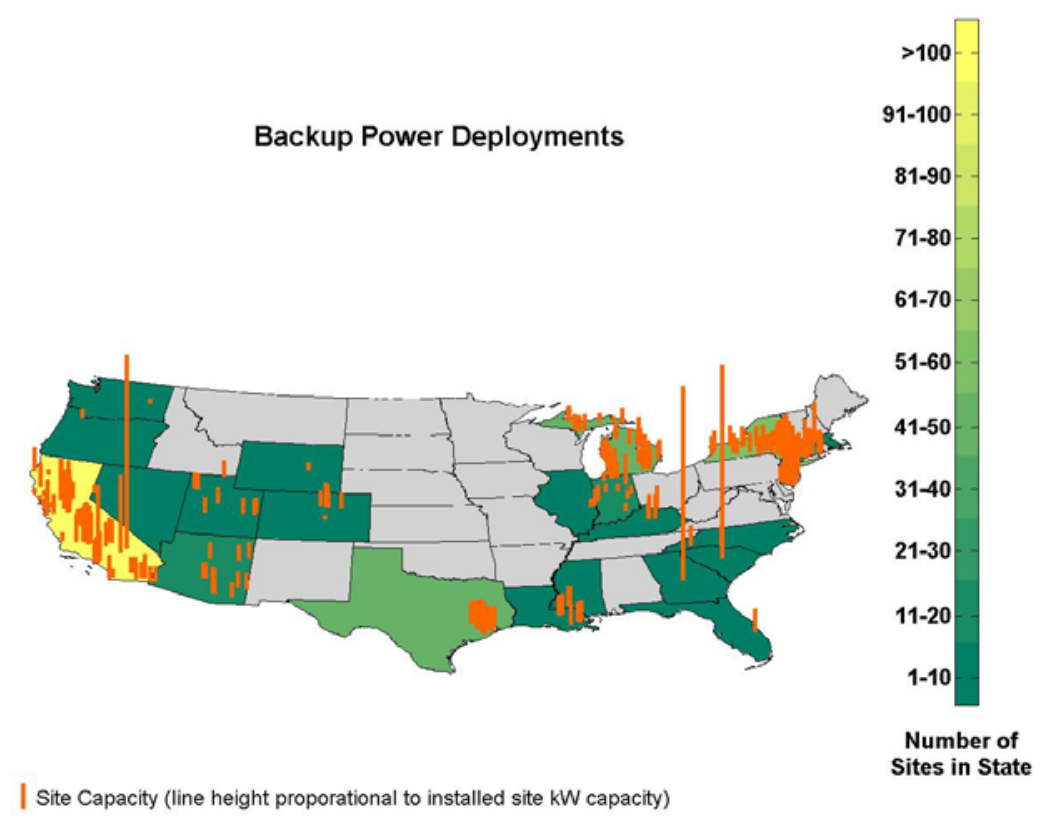

Figure 5. Backup power site locations

A key advancement for fuel cell backup power as a result of the ARRA deployments was the development of a refillable stationary hydrogen storage module (HSM) and accompanying refueling logistics platform for site accessibility, ease of refueling, and decreased delivery costs compared with the cost of changing out hydrogen bottles (Maxwell 2012). Figure 6 and Figure 7 show examples of an HSM and replaceable cylinders. Another consideration for these early fuel cell deployments was choosing a site in proximity to hydrogen distribution facilities, which minimized costs associated with refueling, permitting, installation, commissioning, and training (Kenny 2013).
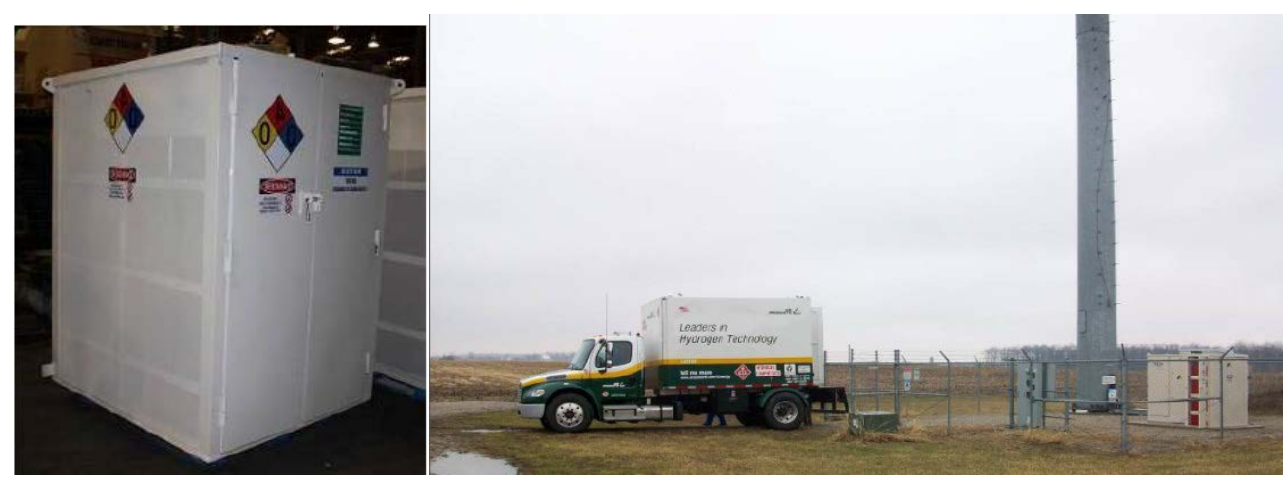

Figure 6. Fill-in place HSM and example fill

(Maxwell 2012) 


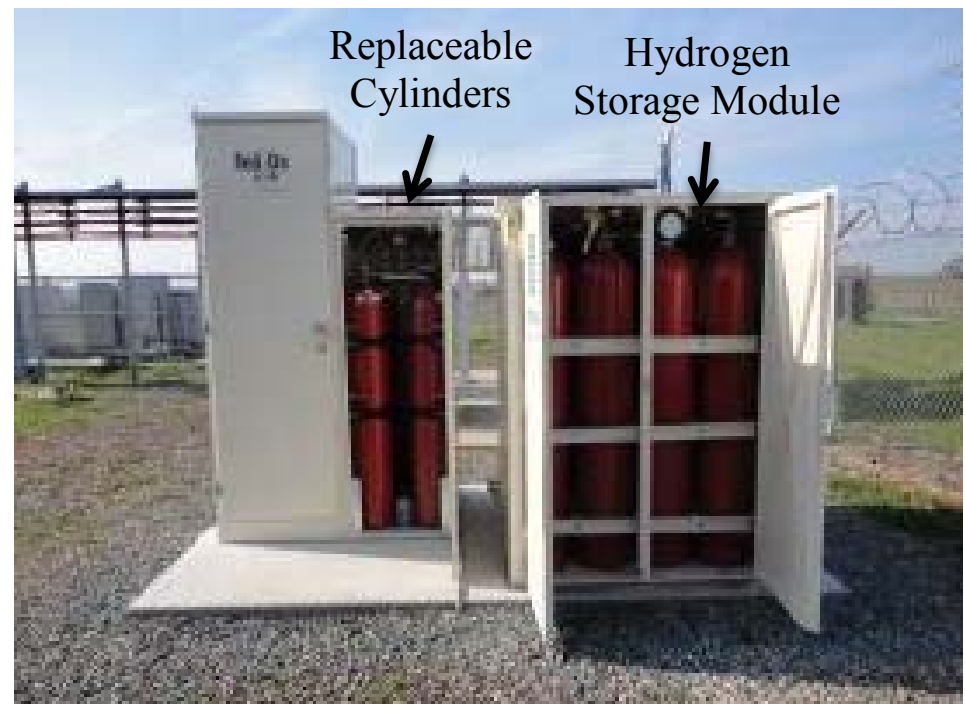

Figure 7. Example ReliOn fuel cell system with replaceable cylinders and an HSM (Maxwell 2012) 


\section{Key Performance Metrics}

Performance in backup power applications is related to the reliability and availability of the fuel cell backup system, the operating characteristics of the fuel cell, and the specific site. Degradation of the fuel cell performance is less of an issue due to the few hours that are accumulated in most backup power applications. These early market deployments did not provide monitoring of the voltage and current to estimate performance degradation. However, operation time, cycles, and shelf life all have an impact on fuel cell durability.

\subsection{Reliability}

Reliability is a key metric. NREL's initial study on reliability simply looked at the number of attempted and successful starts, including forced outages and conditioning runs. The fuel cell systems automatically run conditioning starts that check the system health and keep the system hydrated. During the monitoring period, there were 2,583 uninterrupted operations and only 13 unsuccessful starts, resulting in a $99.5 \%$ availability value. For the purpose of this analysis, an operation is the system operating after a prompt to start. This prompt may either be for a routine system check or because of a grid outage. An interrupted operation is counted if the system did not start when requested or if the system did not complete the full operation period requested.

Figure 8 shows the number of starts by calendar month and the number of systems reporting detailed operation data. NREL is not studying operation data on all of the DOE-sponsored deployments in order to minimize the cost of data collection logistics and maximize the number of units deployed per the funding. The number of systems reporting detailed operation data is identified by the green line plot with the right y-axis; a total of 136 systems were reporting detailed data at the end of 2013.

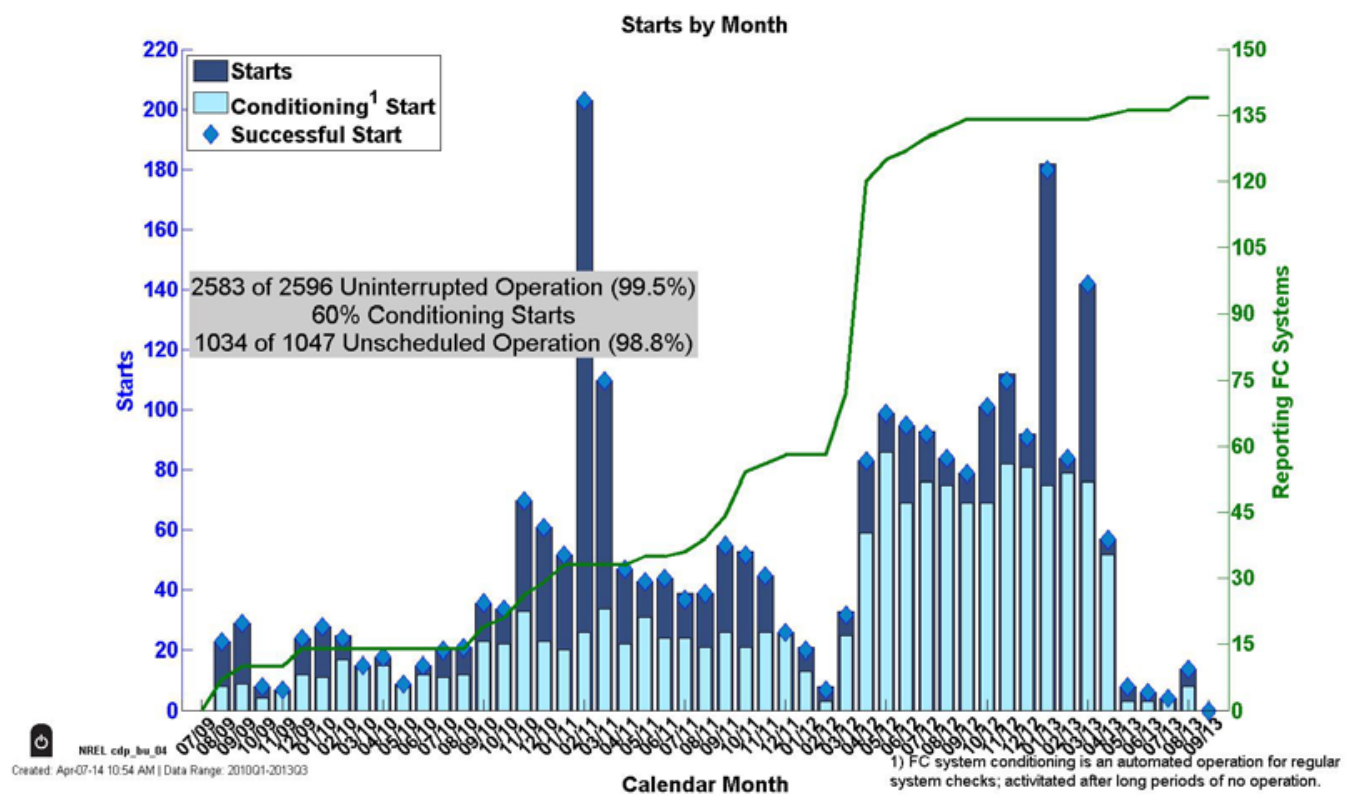

Figure 8. Number of starts by fuel cell backup power units during the analysis period 
The dark blue bars indicate the total attempted starts and the light blue bars indicate the conditioning starts. Just over half of the starts analyzed have been for conditioning. The conditioning starts are relatively short and typically only run if the system has not operated for a while, for example, once a month. The number of starts tracks closely with the number of systems reporting data, with the exception of late 2013, when one of the projects ended according to the award schedule, and early 2011, when a few sites had a high number of starts because of a faulty, non-fuel-cell system component. Subsequent improvements were made to the way the sub-systems are integrated.

There were only 13 interrupted operations during the 3-year monitoring period (Figure 9). System failure was the major cause of eight unsuccessful starts. These system failures varied in cause; some related to the system and integration with the site. Three of the eight system failures were related to a software error in certain situations, which was subsequently fixed. This realworld situational feedback is a critical product development step for fuel cell system manufacturers. The causes for the other five unsuccessful starts were three emergency stops and two instances of no fuel. Additional lessons learned here are based on how sites receive low-fuel alarms and training of site personnel. The emergency stop was likely the result of an operator testing the system and not a safety incident. There are a couple of methods for notifying an operator when the hydrogen storage system is low, dependent on the communications available. A backup power system operates so infrequently that a low-fuel alarm may be sent a long time after the installation of the system, so a clear procedure for refilling the hydrogen storage system is required.

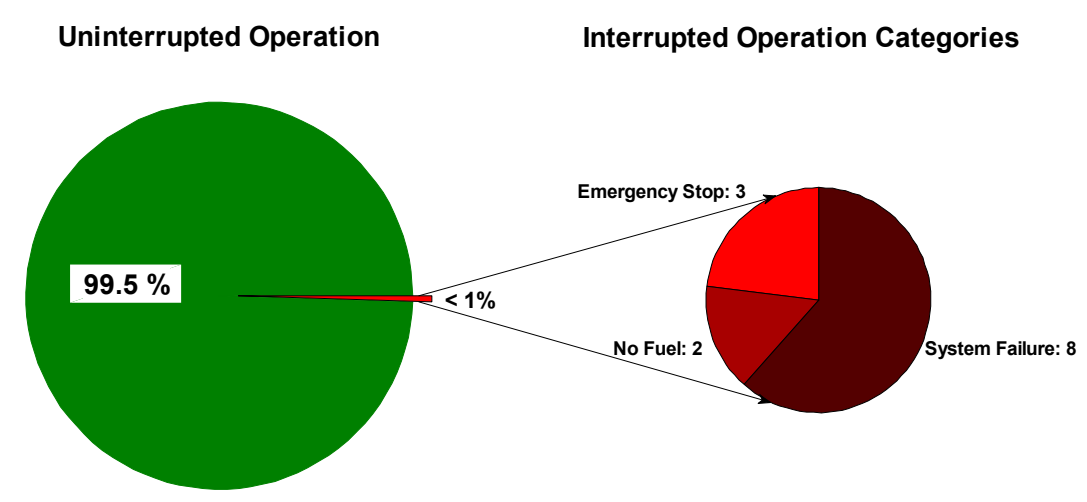

2583 out of 2596 uninterrupted operation

13 interrupted operations

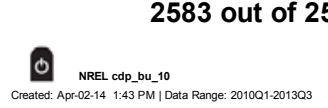

Figure 9. Start reliability of deployed fuel cell backup power units

An additional way to study the backup power system reliability is with mean time between interrupted operation (MTBIO). The MTBIO averages all of the operation periods, in calendar days, based on interrupted operation events. In Figure 10, the majority of systems (94\%) did not experience an interrupted operation during this evaluation period. Of the $6 \%$ of systems that did 
experience an interrupted operation, the median MTBIO was 465 days. Each system had an MTBIO value and there was not a weighting based on the total calendar period that the system was installed and operational. That is, a recently installed system may have a low MTBIO because of an early failure.

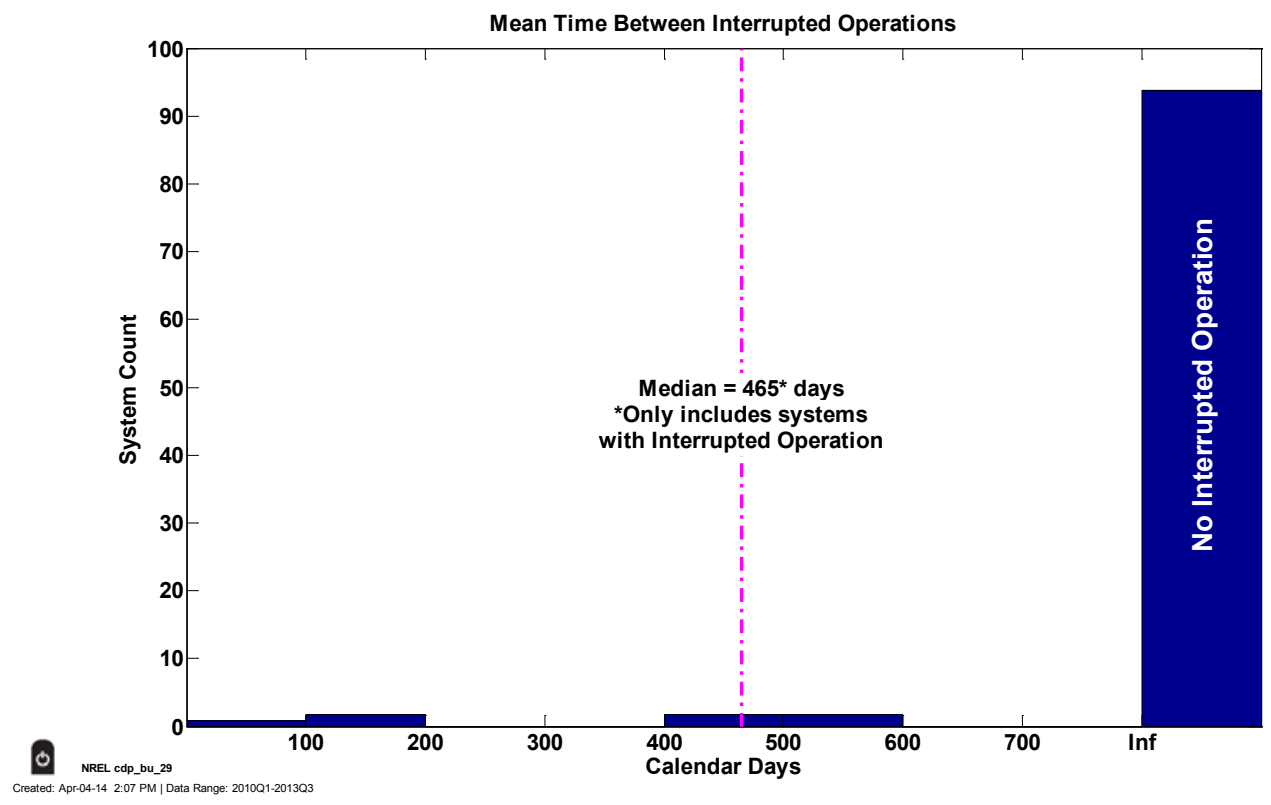

Figure 10. Mean time between interrupted operation

\subsection{Operation Trends}

Backup power is a more intermittent service compared to other applications such as stationary power or vehicle power. The total operating times tend to be very low with long periods of inactivity. However, backup power for key infrastructure elements can aid emergency response during major storms or other devastating events and prevent loss of productivity, time, and money for other grid incidents. The value is in the service backup power provides; however, understanding how the units are operated and needed will help in designing better systems that meet those requirements.

The deployed fuel cell backup power units are being used in the field to support telecommunication towers, a vital service in emergencies. Detailed operation data are available for 136 of the units participating in the study from August 2009 through December 2013. However, some sites and systems were excluded from the analysis due to incomplete data, so the operation analyses only include 120 systems. During the data period, the monitored units logged 1,764 hours of run time (Figure 11). Much of those 1,764 operation hours occurred during conditioning runs, which are used during regular system checks, especially after long periods of no operation, to maintain the health and reliability of the fuel cell. 


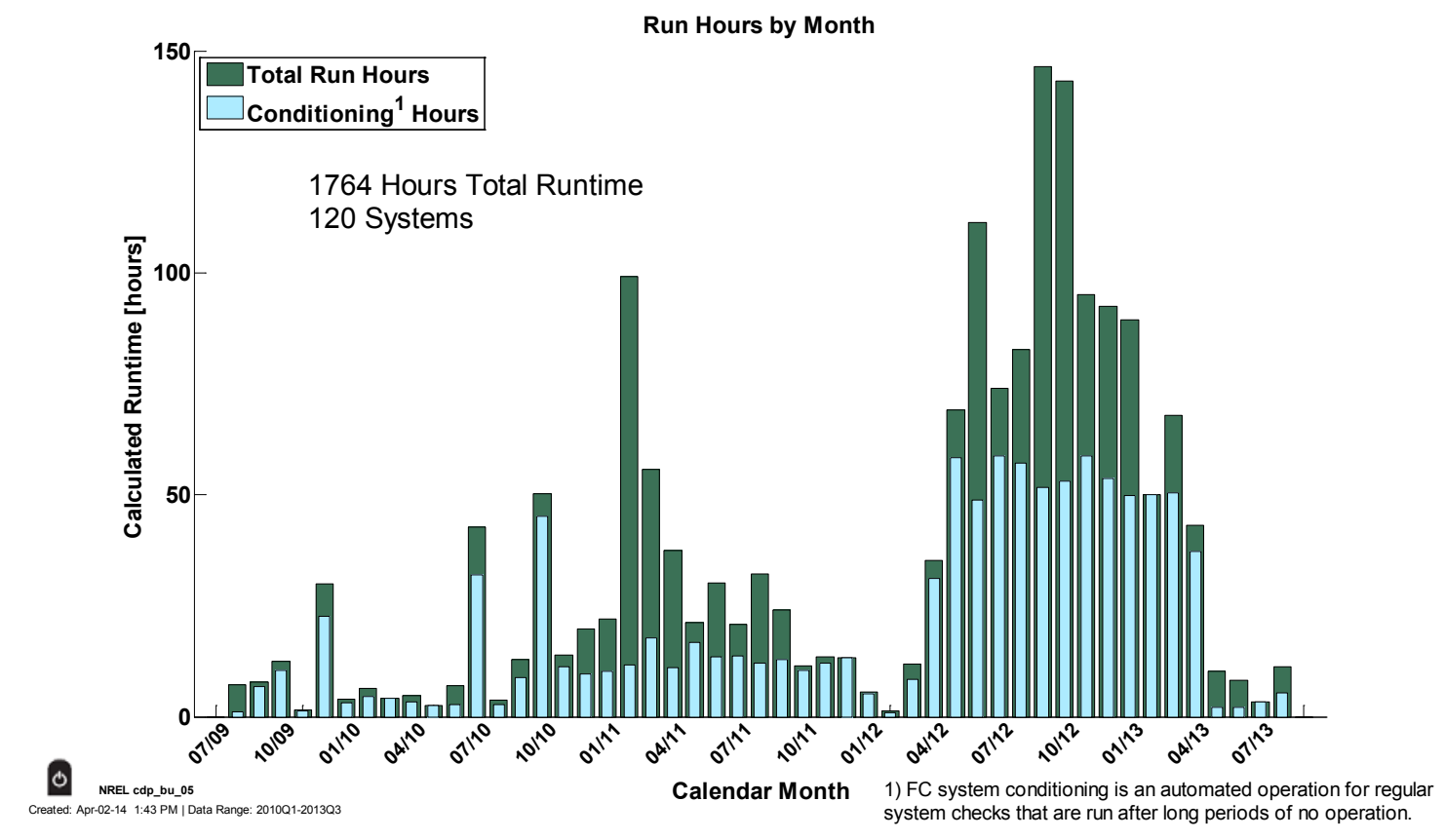

Figure 11. Operation hours per month by fuel cell backup power units deployed

Differences in operation of backup power units can depend on location, local grid stability, and system design for when it is employed, especially when in combination with a battery. About a quarter of the systems deployed accumulated more than 16 hours of operation over the 3-year period; however, units were deployed throughout this time and many were not in operation over the full period. The maximum operating hours accumulated by a single system was more than 70 hours, and the average system operation time was 14.7 hours over the data collection period (Figure 12). 


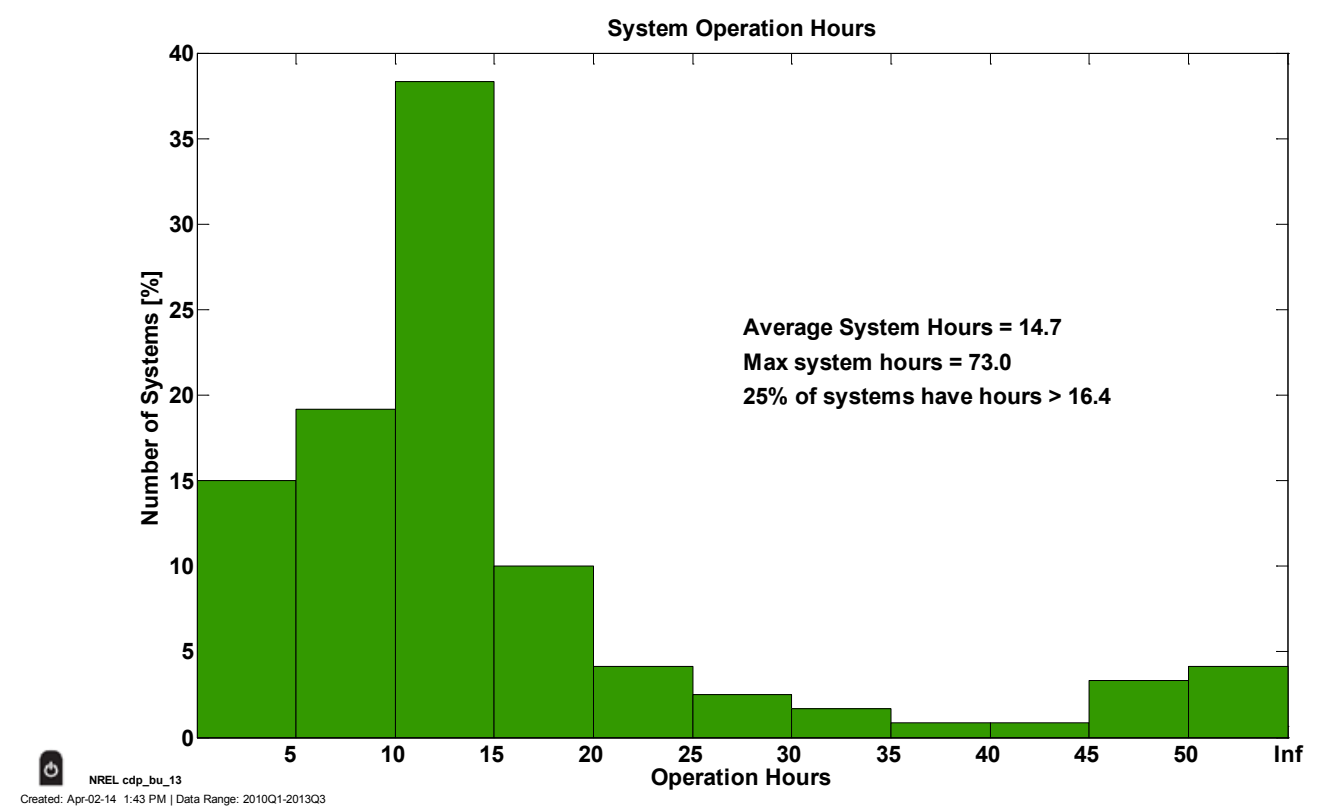

Figure 12. Histogram of total operation hours by fuel cell backup power units deployed

The time between starts varies depending on site and system requirements, but it is rare that the system will be dormant for longer than a month (Figure 13). Almost all of the starts that are 2831 days apart are conditioning starts. The starts that are less than 1 day apart are partially due to systems that come on frequently during an outage, often due to interactions with a battery auxiliary system. This scenario has supplied lessons learned for system integration and perhaps a health check on the accompanying site equipment.

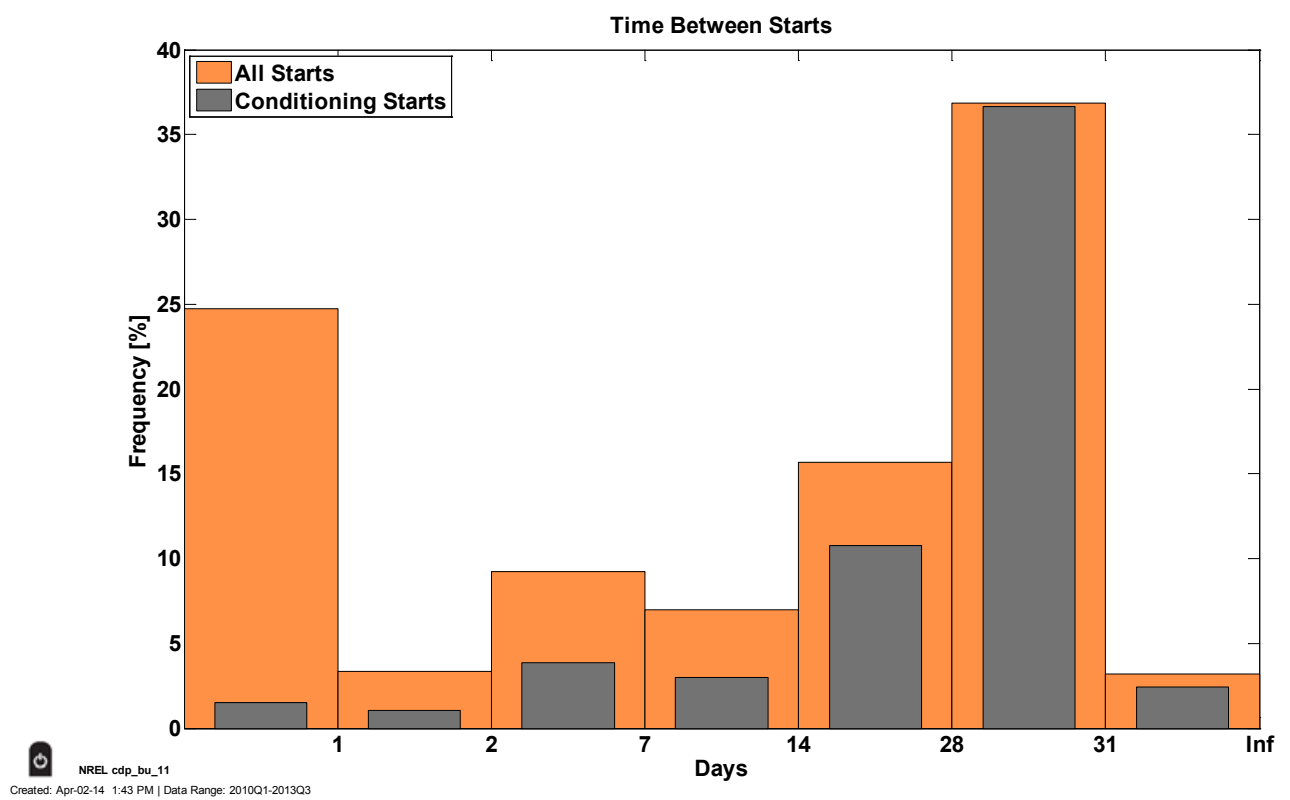

Figure 13. Time between starts with identification of conditioning starts 
The time of day for system starts varies, especially when the system is requested to operate due to a grid failure, but the remote operation of conditioning runs can be timed for off-peak hours to minimize any site impact. For instance, $42 \%$ of starts occur between midnight and 5 a.m. (Figure 14). Conditioning runs are also optimized to minimize fuel consumed and are automatically configured to ensure that the system is ready when needed.

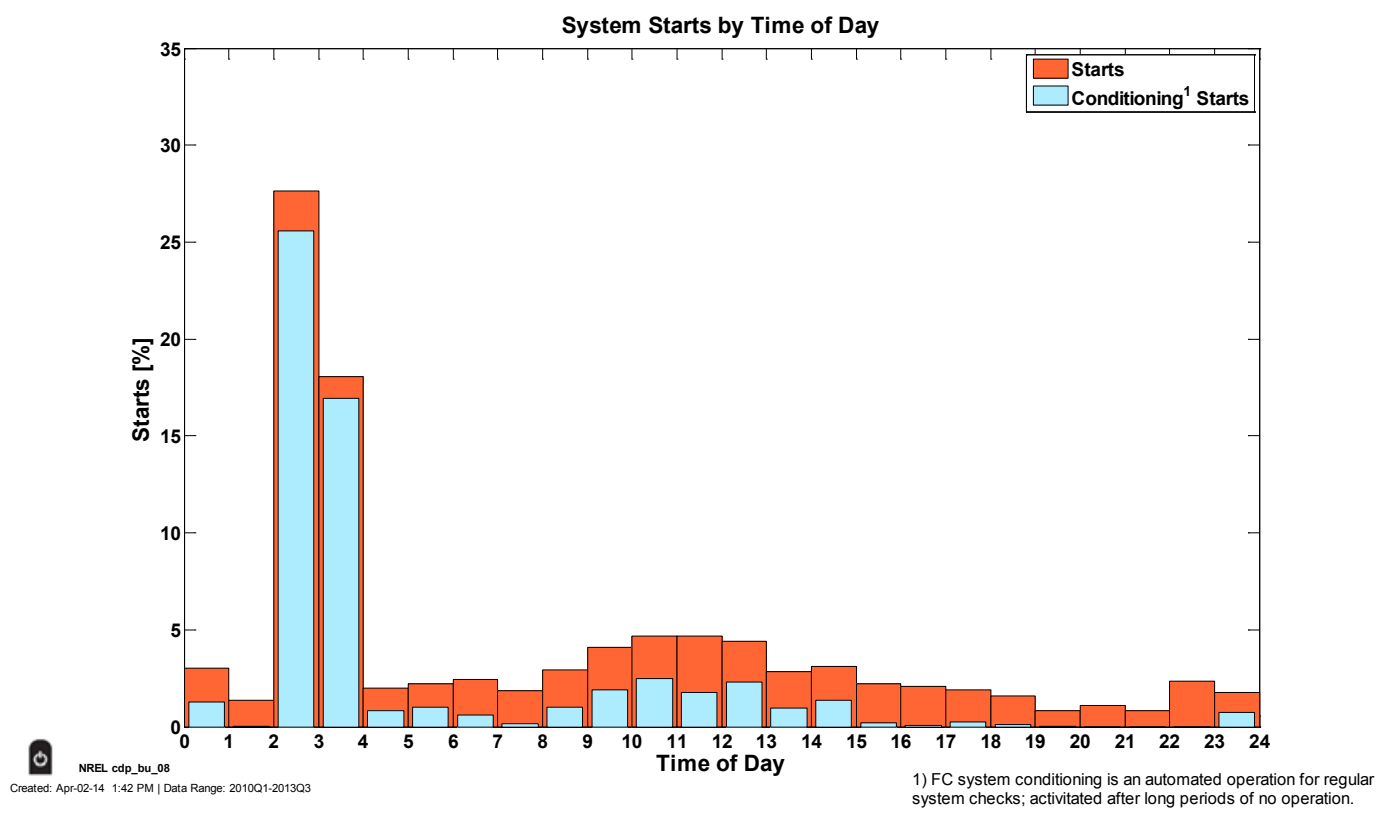

Figure 14. Starts by time of day with identification of conditioning starts

One of the advantages of fuel cell backup power when compared with battery backup power is the ability for extended run times even if most outages are short. As shown in Figure 15, the longest demonstrated continuous run time for a telecommunication tower fuel cell backup unit was 65 hours - close to 3 days; however, the average run time was only 42 minutes. All of the conditioning runs to hydrate the fuel cell and check health were less than 50 minutes. For largescale emergencies and backup of critical systems, this extended (that is, more than 8 hours) run time can be very important. 


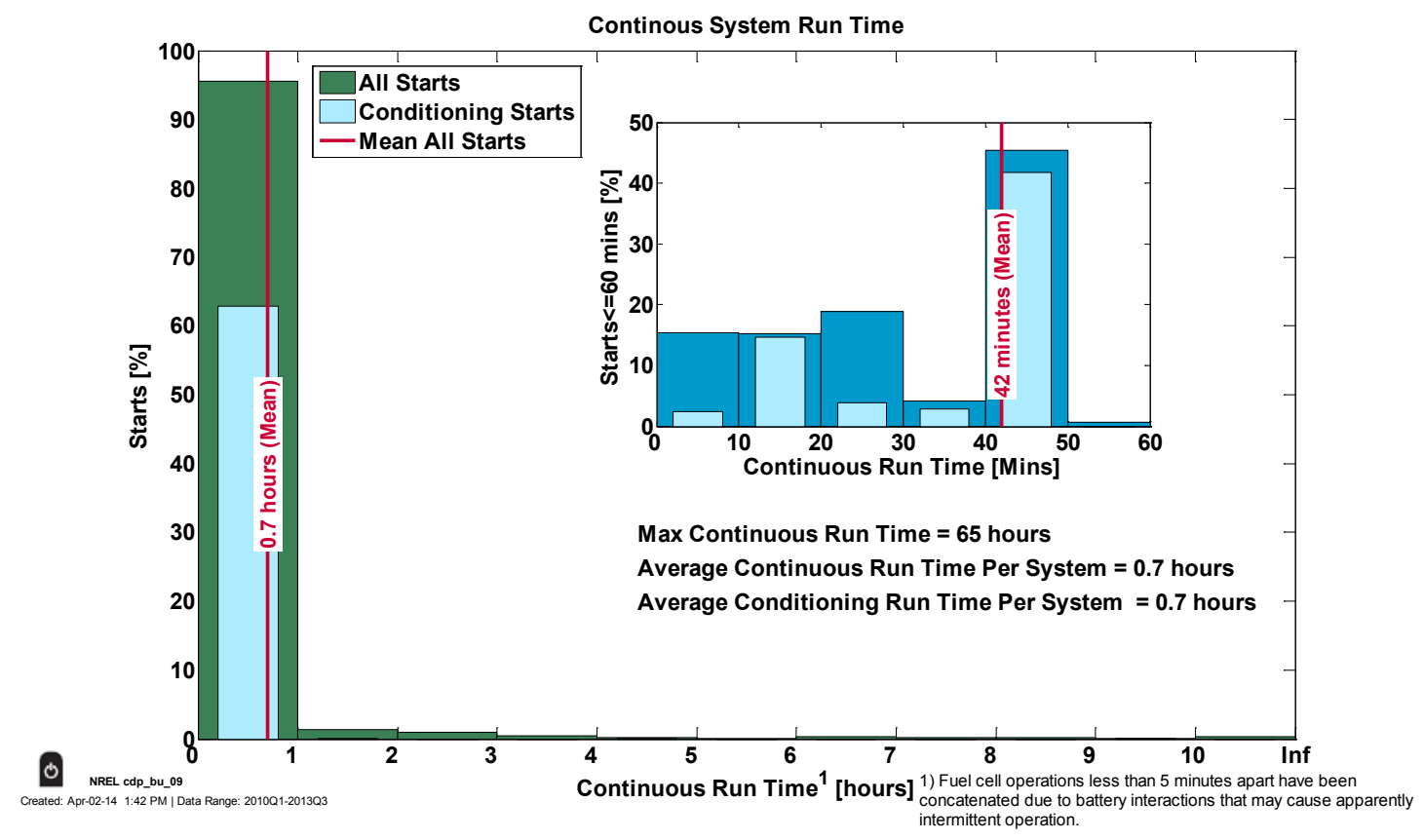

Figure 15. Continuous run time of fuel cell backup units

The intermittent operation of the fuel cells can be seen in the number of starts per month and monthly hours of operation. Approximately $50 \%$ of the systems averaged only one to two starts per month (Figure 16) and about $80 \%$ operated for an average of less than 2 hours each month (Figure 17).

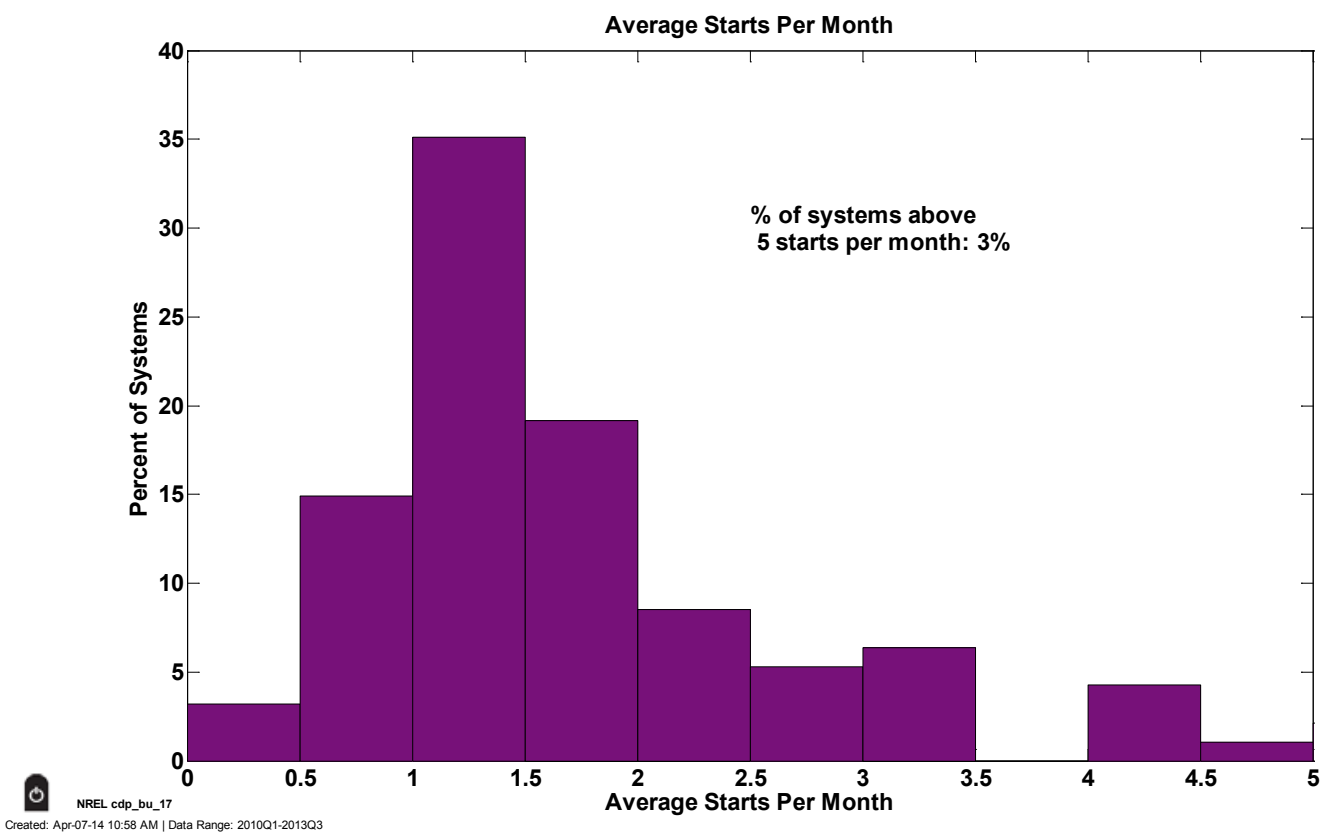

Figure 16. Histogram of average number of starts per month per system 


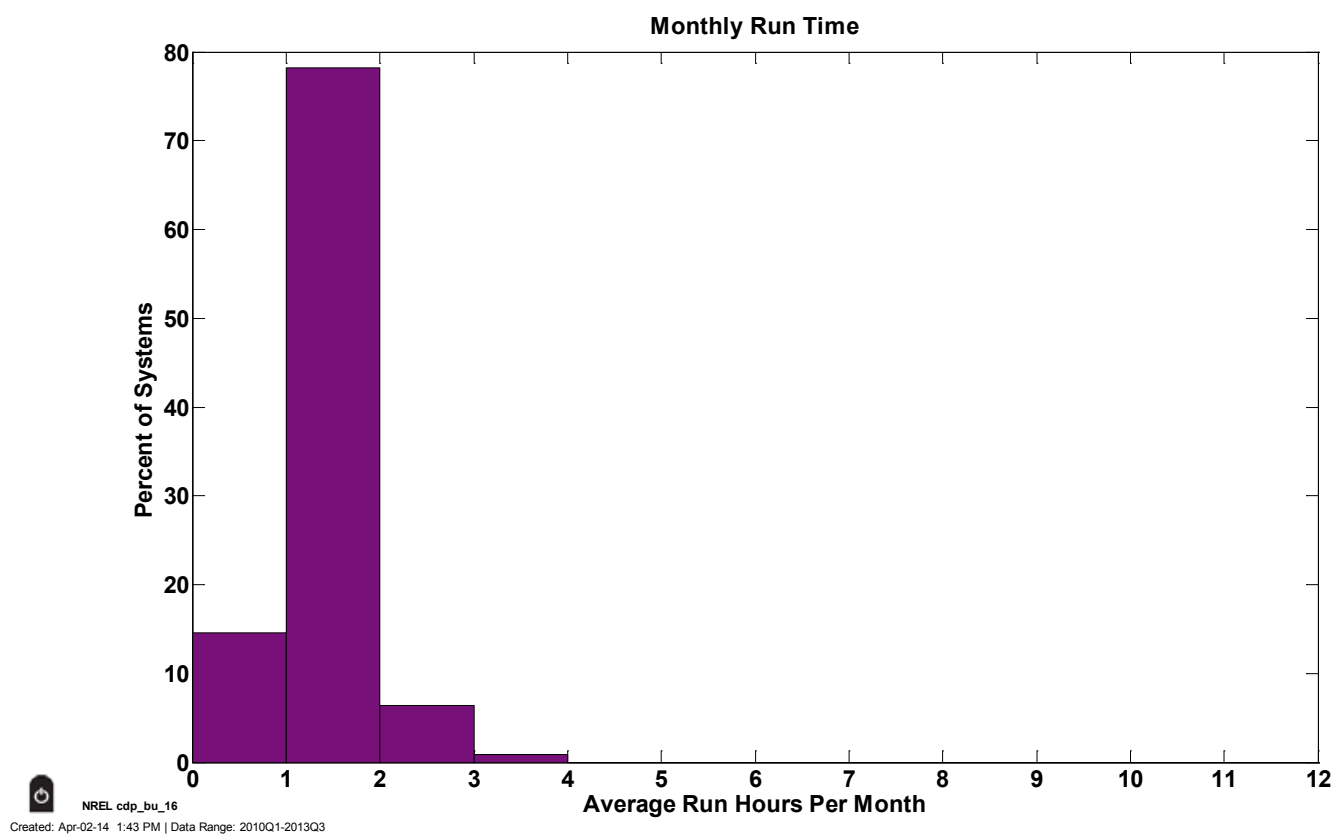

Figure 17. Histogram of average run time per month per system

Many of the operation characteristics are driven by grid outages and stability. In order to better understand this dynamic, NREL analyzed grid data from a DOE database, the Electric Disturbance Event Annual Summaries (Office of Electricity Delivery and Energy Reliability 2014), from 2002 to 2013. The data were analyzed to show numbers of incidents and average outage time. While the local grid will affect specific backup unit operation, these national data can help illustrate what systems face. Figure 18 shows that the number of incidents has seen an increasing trend over time, while the duration has decreased some. Over the whole 11-year period, the average number of incidents by year was 123 , while the average outage duration by year was about 51 hours, or 38 hours when averaging per incident. 


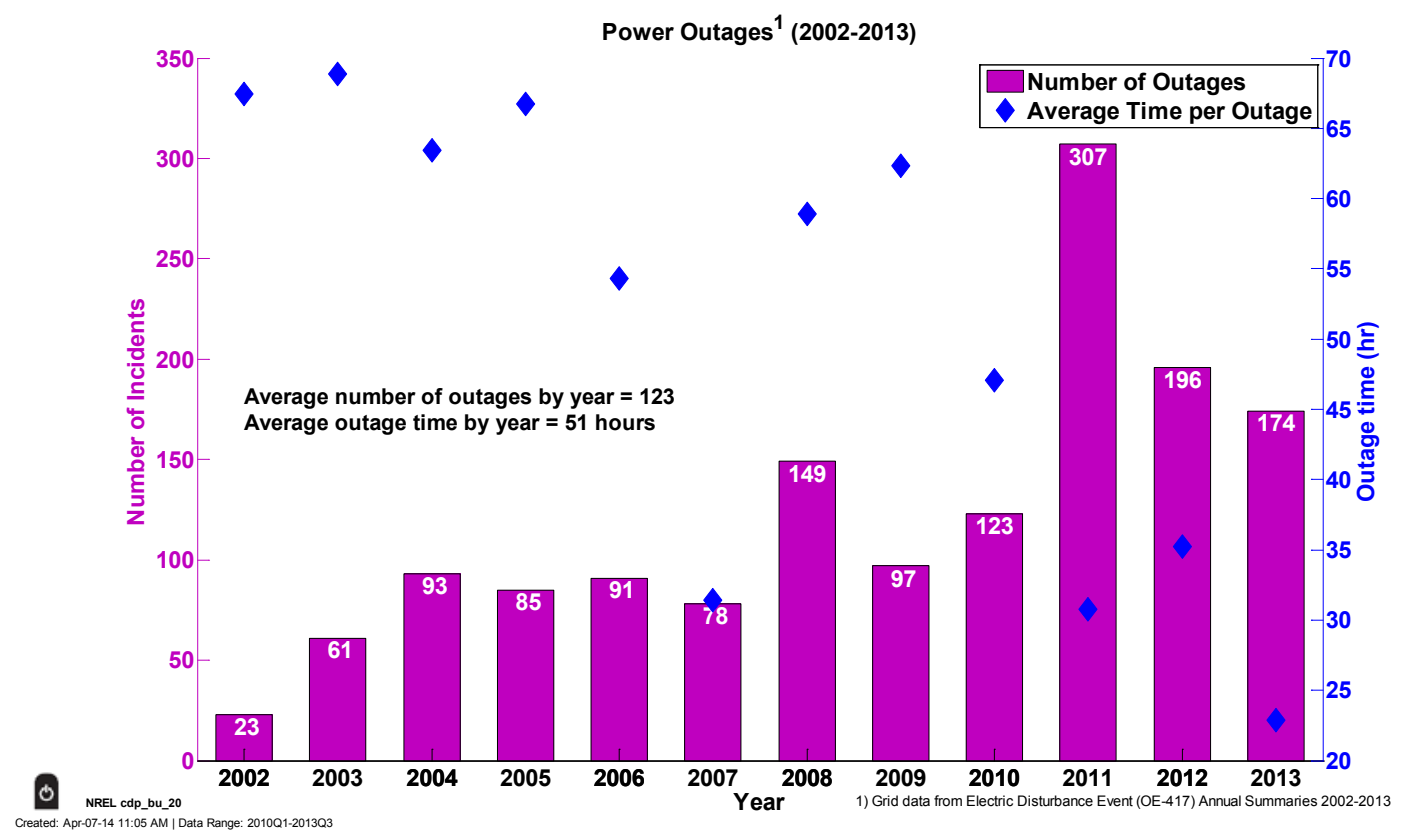

Figure 18. Number and average time of grid outages 2002-2013 from Electric Disturbance Event Annual Summaries

(Office of Electricity Delivery and Energy Reliability 2014)

NREL developed an animated movie (NREL 2012, NREL 2014) that shows a visual representation of the grid incidents and fuel cell operation. The major grid outages are overlaid with installation locations and dates as well as operation data for select fuel cell backup units and synthesized into a time-lapse geographical visualization map. The interactive map allows the user to click or play through the highlighted events to analyze usage patterns in conjunction with major grid outages. A snapshot is shown in Figure 19.

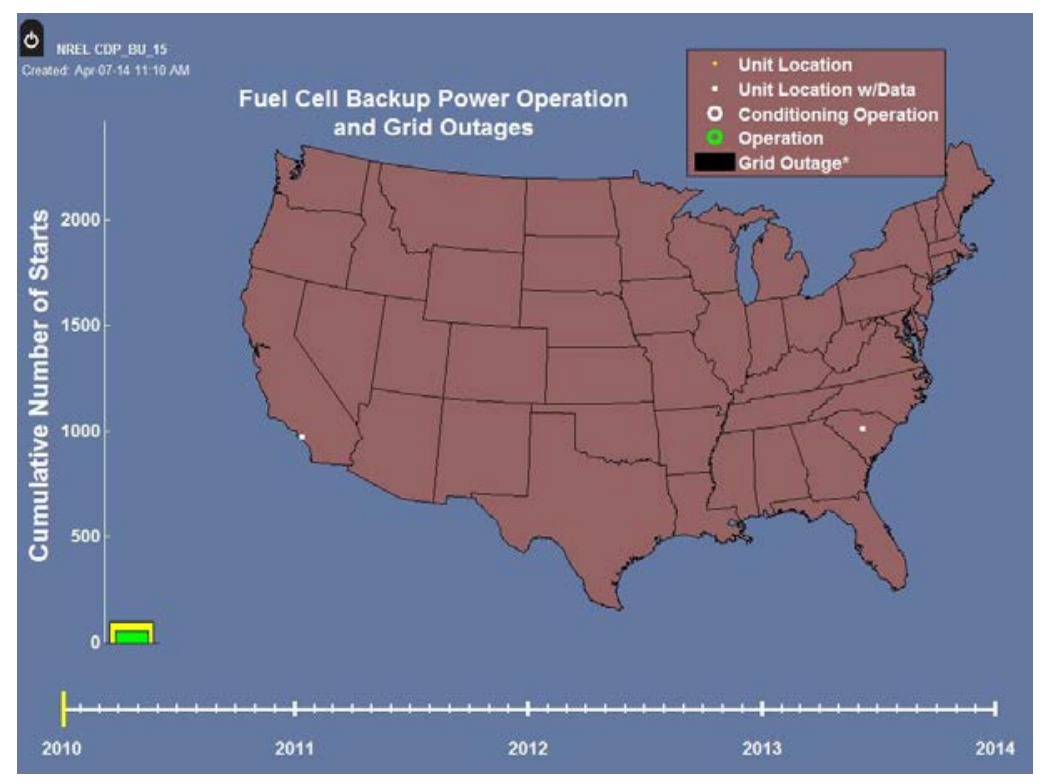

Figure 19. Snapshot of the fuel cell backup power animated visualization map View the full animation at http://youtu.be/Hq 5BpQM1bk (NREL 2014) 
These systems are deployed in diverse climates (both cold and hot weather operation, but no operation below freezing because the systems employed a "keep warm" strategy using a heated enclosure). The ambient temperature at the start of the systems' deployment is shown in Figure 20. The temperature data in cold climates is from the heated enclosure.

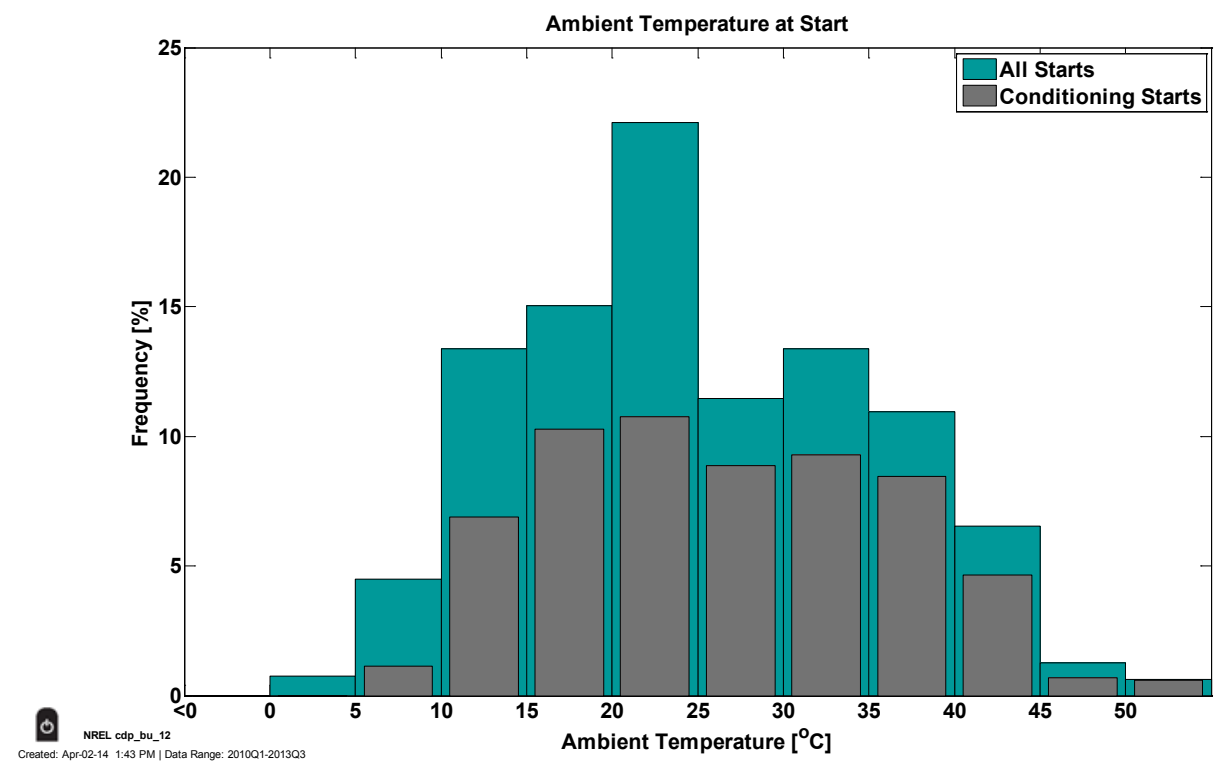

Figure 20. Ambient temperature at start-up of backup power fuel cell units

The importance of extended run time can be seen more specifically in context with major known events. Looking at grid data from the times of several major hurricanes (Sandy, Irene, and Isaac), the average outage during the hurricanes was almost 87 hours, with a low of 56 hours for Hurricane Irene and a high of 143 hours for Hurricane Sandy (Figure 21). The median grid incident duration from the unfiltered data set was only 11.7 hours. The demonstrated duration statistics included in Figure 21 only include non-conditioning operation. While backup power systems can be designed for the most probable outage duration, extended run times for critical systems are needed for this small set of longer-duration emergencies.

During Hurricane Sandy (October 29 through November 12, 2012), fuel cell backup power units were already installed at 122 ARRA sites in the impact area identified by the Federal Emergency Management Agency (FEMA) Modeling Task Force (MOTF) analysis (FEMA 2014) (Figure 22). Figure 22 includes a zoomed inset of the New Jersey area where five sites reported operation during Hurricane Sandy for a total of 112 hours of operation. 


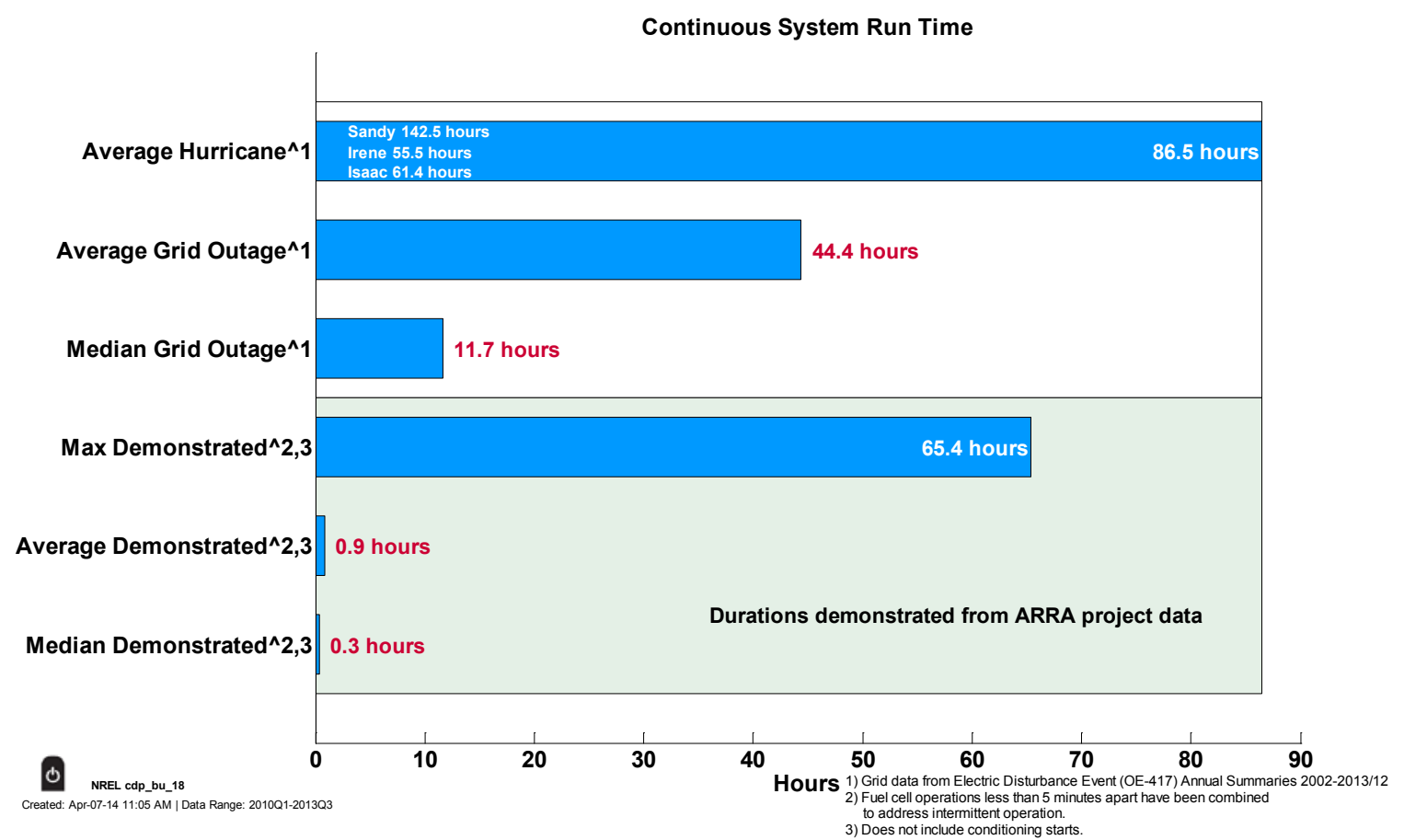

Figure 21. Comparison of grid events to fuel cell backup power operation

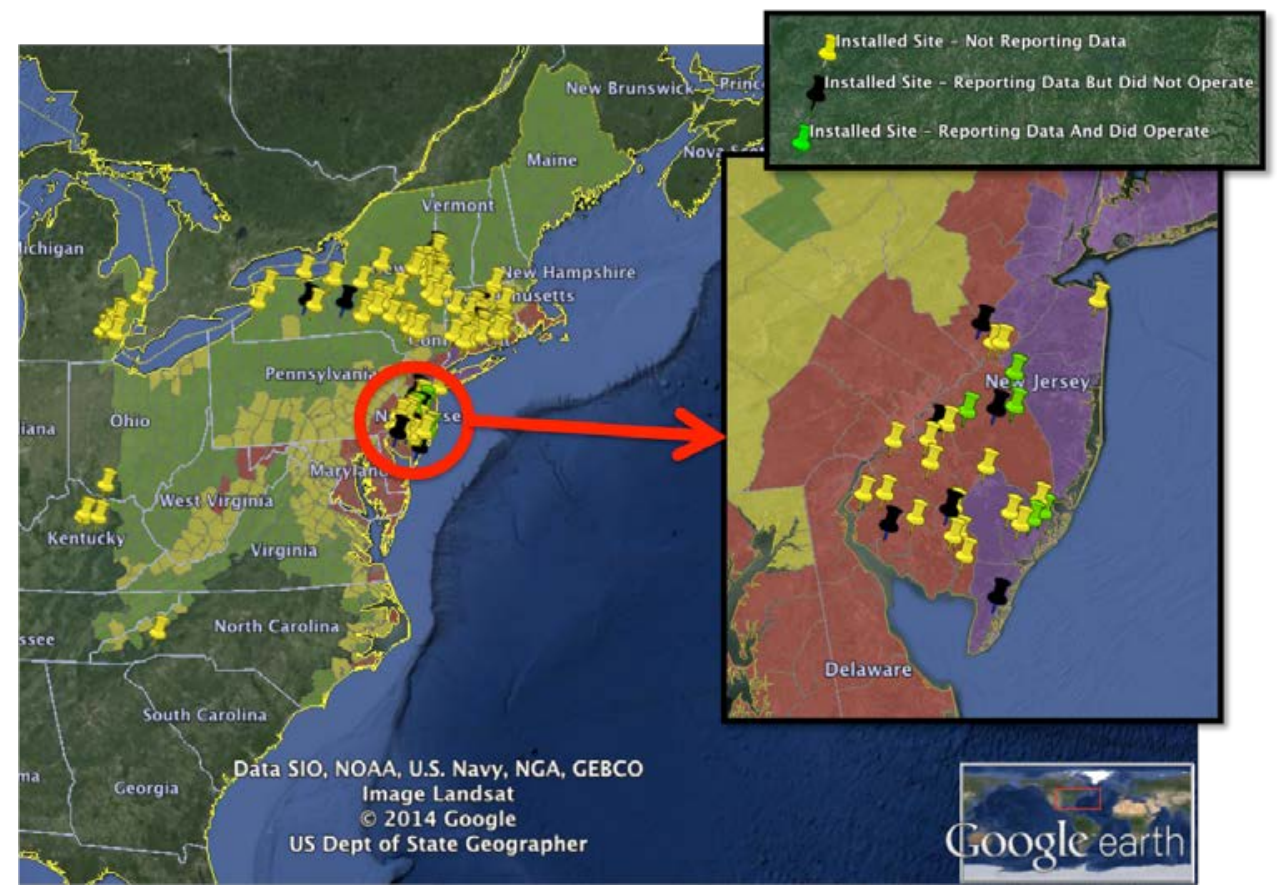

Figure 22. ARRA backup power site locations in FEMA MOTF impact area for Hurricane Sandy.

Yellow pins: sites with systems already installed but not reporting data to NREL. Black pins: sites reporting data to NREL but systems did not operate during Hurricane Sandy. Green pins: sites reporting data to NREL with systems that operated during Hurricane Sandy. 


\section{Value Proposition}

General performance metrics for backup power operators are reliability, cost, run time, and emissions. The economics of backup power applications have three major factors: 1) the initial capital investment; 2) the opportunity costs of system downtime, which hinge on the reliability and availability of the backup system; and 3) the ongoing operating costs related to ongoing maintenance activities and fuel delivery cost. Other factors that can impact backup system selection are noise, emissions, and environmental issues, especially when considering urban versus rural installations.

NREL requested cost of ownership data including site description, system description, requirements, capital cost, operating and maintenance cost, and operating lifetime for fuel cells, batteries, and diesel systems. The value proposition analysis began as a plus-minus chart (Table 2) that was assembled based on the authors' interpretation of detailed fuel cell data, literature search, and knowledge of site operation and requirements.

Table 2. Qualitative Comparison of Backup Power Technologies

\begin{tabular}{lccc}
\hline & Fuel Cell & Diesel & Battery \\
\cline { 2 - 4 } Reliability & + & - & + \\
Capital cost (\$/kW) & - & + & ++ \\
Extended run time & ++ & ++ & -- \\
Emissions & ++ & - & ++ \\
Noise & + & - & ++ \\
Weight & + & - & - \\
Efficiency & + & - & ++ \\
Annual fuel cost & + & - & ++ \\
Annual maintenance cost & + & - & ++ \\
Maintenance frequency & ++ & - & $\sim$ \\
Refurbishment & + & + & -- \\
Remote conditioning and check & + & - & $\sim$ \\
Operation lifetime & + & ++ & -- \\
\hline
\end{tabular}

The chart utilizes a range of "++" (much better than the comparison technologies) to "- -" (much worse than the comparison technologies). A " $\sim$ " indicates details are unknown or do not apply for that technology metric. The fuel cell cost does include a federal investment tax credit, available until December 31, 2016, of $\$ 1,500$ per $0.5 \mathrm{~kW}$ or $30 \%$ total cost (DSIRE 2014a). A range of credits, grants, and other financial tools is available at the federal and state levels (DSIRE 2014b). While the capital cost of the fuel cell systems remains an obstacle, there are other benefits to fuel cells that can start to offset the initial investment while the industry grows.

A fuel cell system and a battery system are very comparable in most of the metrics except for capital cost and extended run time. If a site is willing to only have backup power for 8 hours or 
less, the battery-only system tends to be the lowest cost option. If a site requires extended run time (due to regulations and/or risk management), then a fuel cell system or a diesel generator is the right system. If extended run time is required, emissions, reliability, and noise are the bigger differentiators between fuel cell systems and diesel generators; emissions and noise are particularly factors in urban environments.

NREL also completed a detailed cost of ownership analysis and published the results through CDPs and a report [1]. An annualized cost of ownership analysis enables a better understanding of the value proposition for fuel cell backup power systems when compared with the incumbent technologies of battery and diesel generator systems. Backup power operation can vary widely based on region, end user, and site-specific requirements, so a number of assumptions are made to compare three different backup power technologies (diesel, battery, and fuel cell) operating in similar circumstances in four run time scenarios $(8,52,72$, and 176 hours). These are the same run times used in the Battelle report, "Identification and Characterization of Near-Term Direct Hydrogen Proton Exchange Membrane Fuel Cell Markets" (Mahadevan et al. 2007). Each run time scenario assumes the system operates for a specific amount of hours annually; for example, a system in the 72 -hour scenario operates for 72 hours a year. The 72 hours could be accumulated through many shorter run operations or through one continuous operation. The actual use of a telecommunication system is not as simple, or as prescribed, as these run time scenarios.

Figure 23 displays the annualized cost estimates for each run time scenario and technology. The battery cost of ownership increases significantly with the higher run time scenarios, and this technology is unlikely to be a truly stand-alone solution for situations that require high run times. The fuel cell system with incentives ${ }^{4}$ (denoted $\mathrm{FC}^{*}$ in figures) is cost competitive with the diesel generator, particularly in the 8-hour, 52-hour, and 72-hour run time scenarios. The fuel cell system has a higher efficiency and less frequent maintenance schedule than the diesel generator does, and the incentives offset the higher capital and installation costs. Other backup power technology attributes not tracked in this cost of ownership analysis- but which may be key decision factors along with the cost of ownership - include noise, emissions, equipment footprint, available installation space, and permitting.

\footnotetext{
4 "The credit is equal to $30 \%$ of expenditures, with no maximum credit. However, the credit for fuel cells is capped at $\$ 1,500$ per 0.5 kilowatt $(\mathrm{kW})$ of capacity. Eligible property includes fuel cells with a minimum capacity of $0.5 \mathrm{~kW}$ that have an electricity-only generation efficiency of 30\% or higher." (DSIRE 2014a)
} 


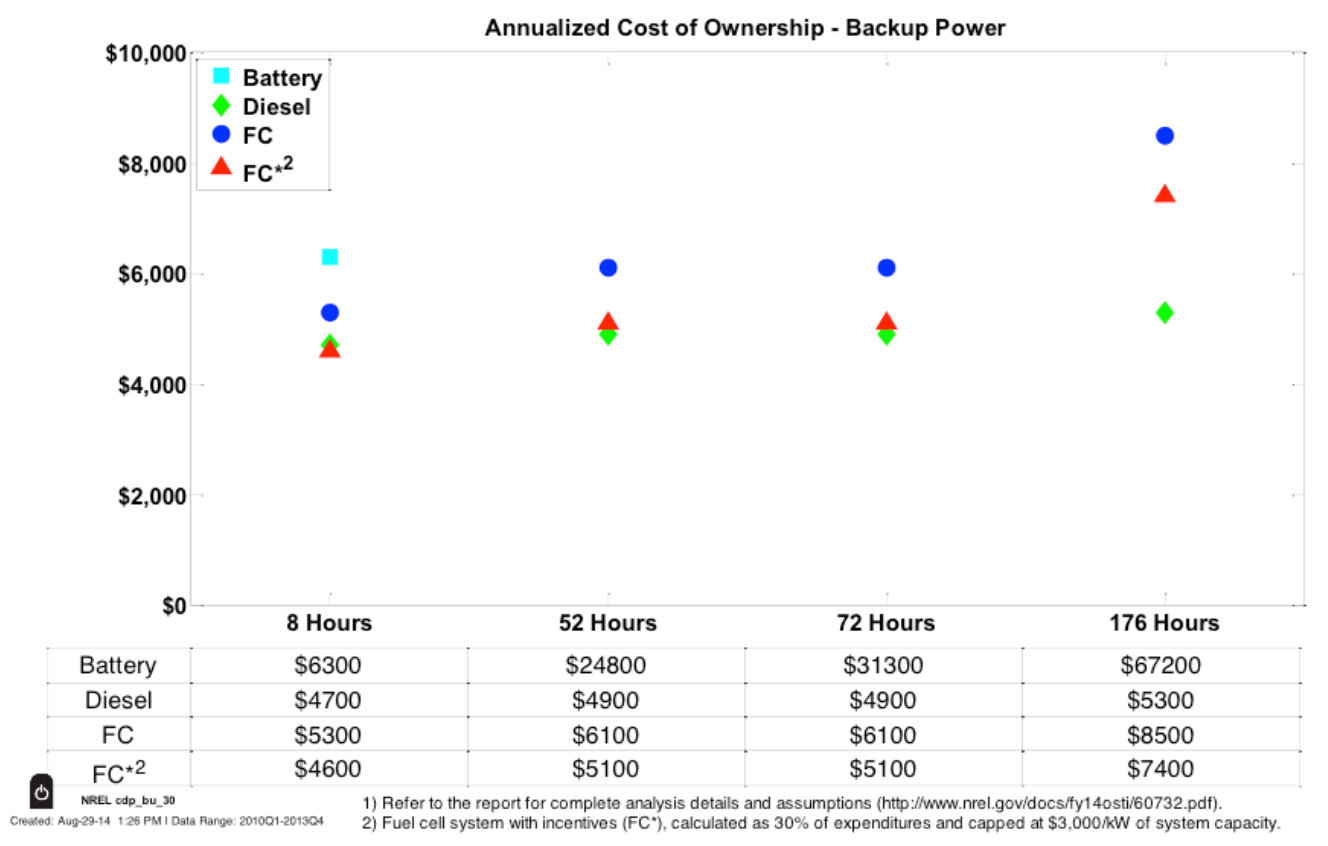

Figure 23. Annualized cost of ownership technology comparison for multiple run time scenarios (battery cost is only plotted for the 8-hour scenario)

Fuel cell systems are now cost competitive with the incumbent backup power technologies, according to NREL's cost of ownership analysis, especially with incentives. In the 72-hour run time scenario (Figure 24), the cost of ownership of the fuel cell system, without incentives, is approximately 1.2 times higher than that of a diesel generator and more than 5 times lower than that of a battery system. In the same run time scenario, the cost of ownership of the fuel cell system, with incentives, is approximately equal to that of the diesel generator and more than 6 times lower than that of a battery system. Refer to the report (Kurtz et al. 2014) for detailed costs, assumptions, and results. 


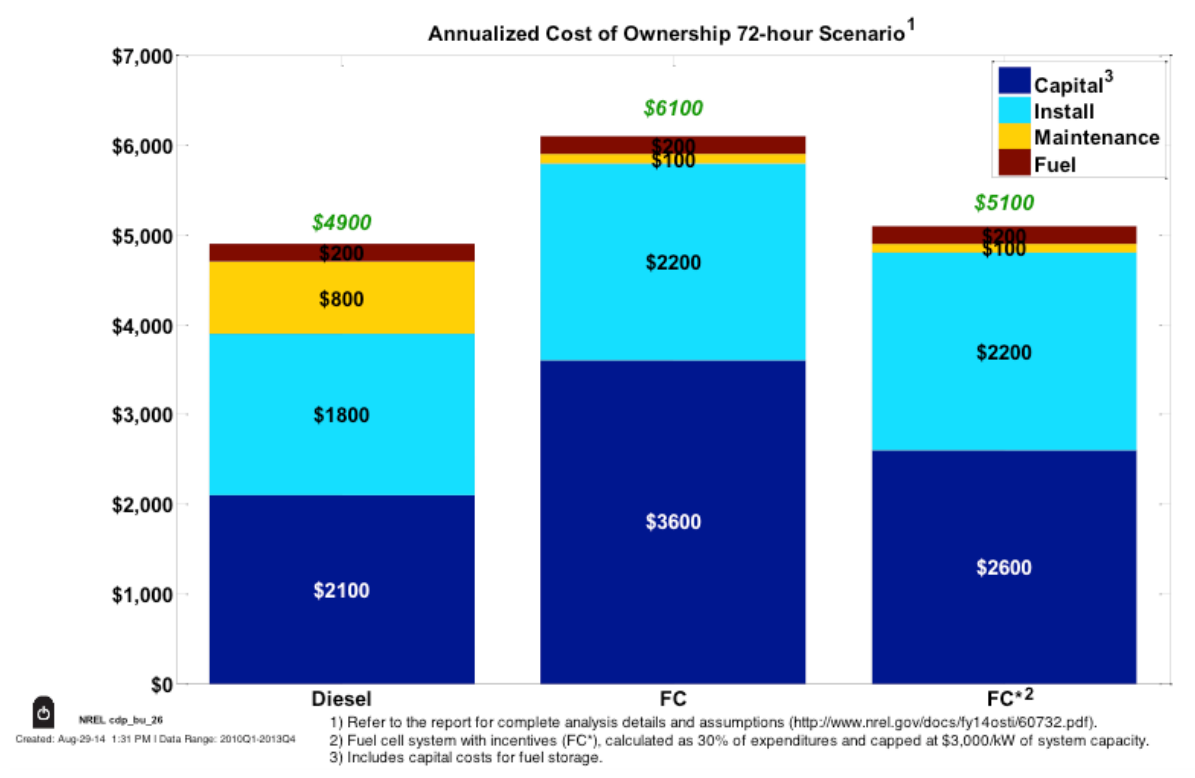

Figure 24. 72-hour scenario annual cost breakdown

In order to capture the variability of assumptions and input data, NREL completed a sensitivity study of capital costs, installation costs, discount rate, operation life, maintenance costs, and fuel/electricity costs for the 72-hour run time scenario. Figure 25 shows the annualized cost of ownership ranges from the 72-hour sensitivity study. The inputs that have the largest range in cost of ownership are capital costs, installation costs, and operation life. These three have the greatest variation with input data and uncertainty. For example, the fuel cell operation life of 15 years is an input assumption that has not been validated through NREL's technology validation of fuel cell backup power systems in real-world operation. Fuel cost, discount rate, and maintenance have relatively small ranges and therefore small impact on the annualized cost of ownership. These inputs have a small impact on the annualized cost of ownership partly because the systems operate for very little time during a year. This emphasizes the importance of the initial capital and installation costs on the perceived and actual cost of ownership of backup power systems. For reference, the average annualized cost of ownership (from Figure 24) is identified in Figure 25 as a red line. 


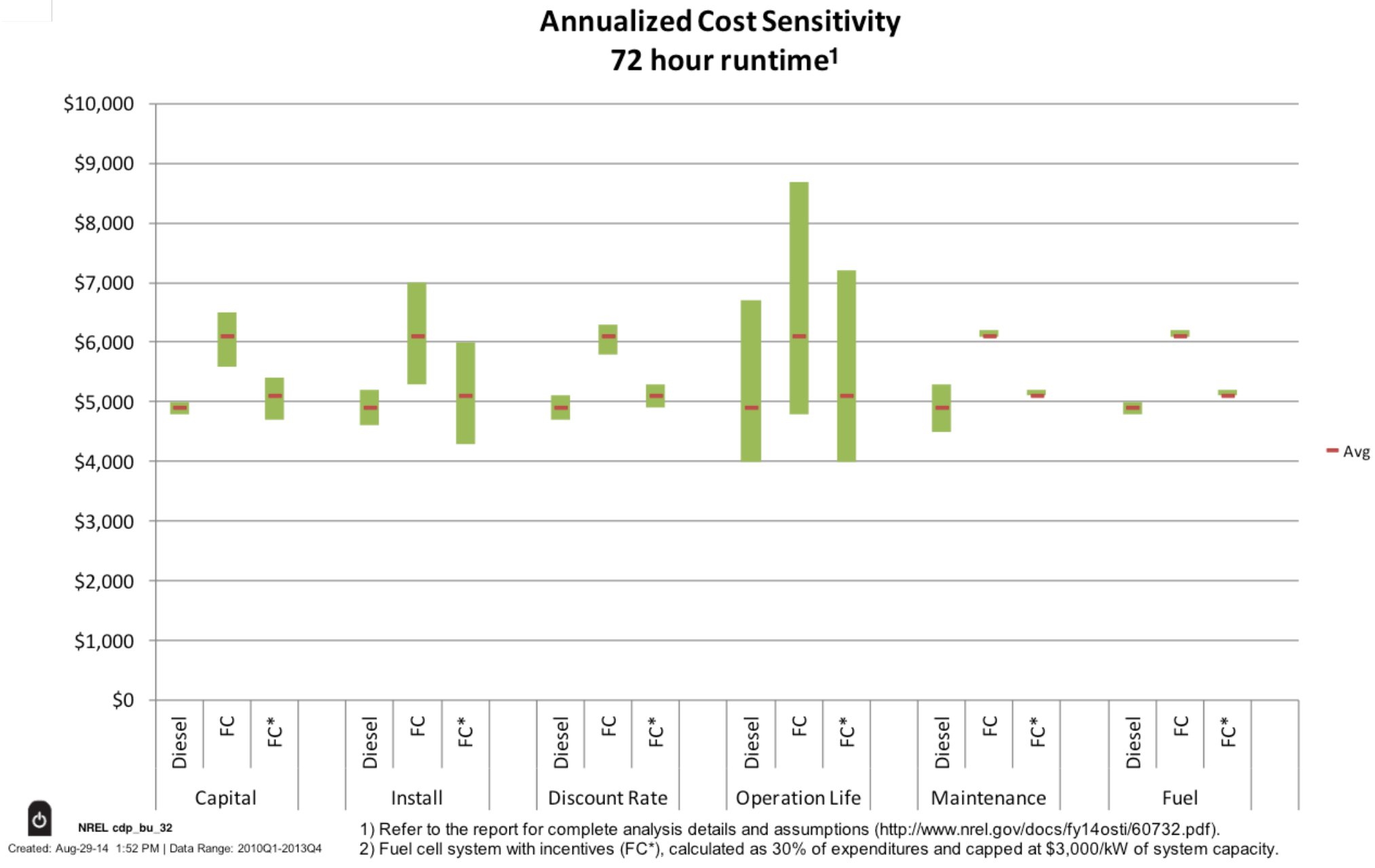

Figure 25. 72-hour sensitivity analysis results 


\section{Conclusions}

The ARRA co-funded deployment of early market fuel cell backup power systems has enabled a significant amount of industry growth and resulted in a number of lessons learned. The deployment of 1,330 fuel cell units, of which 852 were used for backup power, exceeded the Fuel Cell Technologies Office's ARRA target of 1,000 fuel cell units. Additionally, the deployment vitalized the industry in several ways, including quantification and validation of fuel cell system performance metrics and costs. The successful deployments show the technical viability of a cleaner alternative to the incumbent backup power technologies.

Technologically there were several advancements and improvements, both direct and indirect. Development of a refillable hydrogen storage module and refueling platform increased accessibility and decreased costs of hydrogen infrastructure. The real-world deployments helped to disperse permitting and siting knowledge in many different regions, and auxiliary services related to maintenance, material and component suppliers, and installation were augmented.

The deployments were in 23 states, in diverse climates and urban and rural environments, and most site capacities were between 4 and $6 \mathrm{~kW}$. More than 850 backup fuel cell units were deployed in the project. Of the total deployed systems, 136 systems provided detailed operation data to NREL for validation analysis. The monitored fuel cell units had 2,596 attempted starts with only 13 failures for a $99.5 \%$ start ratio. The failed operations helped identify software glitches in the systems. Table 3 summarizes the current performance status of the analyzed systems and topics for future analyses. The fuel cell systems were monitored remotely, and conditioning runs were implemented to regularly check the system status and keep the fuel cell stack hydrated. The conditioning runs accounted for $60 \%$ of the starts analyzed, so there were a large number of site-requested starts. Those starts were initiated for either a grid outage or a low battery voltage signal.

A reduction in capital and installation costs will result in a stronger value proposition for fuel cell systems as backup power solutions. The cost and the difficulty associated with the permitting of hydrogen systems are other areas that require development for widespread deployment of fuel cell systems. These permitting challenges can vary greatly across the country and can be addressed by the consistent implementation of codes and standards. For decision makers selecting a backup power system, the initial costs are key drivers, but other aspects to consider are noise, permitting, emissions, run time capability, ease of refueling, footprint, and user comfort with the technology. 
Table 3. Fuel Cell Backup Power Performance Status Summary

\begin{tabular}{|c|c|}
\hline Metric & Status \\
\hline Lifetime & $>4$ years analyzed (estimated $\sim 10$ years) \\
\hline Durability & 2,400 hours to $10 \%$ voltage degradation ${ }^{a}$ \\
\hline Efficiency & $\begin{array}{l}\text { Data not included in NREL's validation } \\
\text { project }\end{array}$ \\
\hline Mean time between failure & TBD (13 failures out of 2,578 of starts) \\
\hline Ambient temperature range & $0^{\circ} \mathrm{C}$ to $50^{\circ} \mathrm{C}$ in all-weather enclosures \\
\hline Noise & $\begin{array}{l}\text { Data not included in NREL's validation } \\
\text { project }\end{array}$ \\
\hline Start-up time & Instantaneous with battery hybrid system \\
\hline Maximum continuous run time & 72 hours target, 65 hours demonstrated \\
\hline Reliability & $99.5 \%$ \\
\hline Equipment cost & $\begin{array}{l}\$ 5,700 / \mathrm{kW} \text { (without storage, } 72 \text {-hour annual } \\
\text { operation) }\end{array}$ \\
\hline Total cost of ownership & $\begin{array}{l}\$ 6,100 / \text { year (72-hour annual operation, no } \\
\text { incentives) }\end{array}$ \\
\hline
\end{tabular}

a NREL 2013b

b Kurtz et al. 2014

Validation with real-world data has helped to highlight the need for better system integration, sizing, and operation requirements. Research and development needs include the following:

- Gain a better understanding of the integration between the fuel cell system and the site. For instance, fuel cells and batteries are often paired, requiring knowledge of dispatch controls, sizing optimization, and system controls.

- Develop best practice maintenance procedures to minimize interrupted operation.

- Develop lower-cost hydrogen infrastructure storage and delivery options.

- Improve siting and permitting procedures to decrease time, complexity, and cost of selecting a site. The site selection and permitting takes significantly more time than the actual equipment installation and commissioning. Telecommunications sites vary in location, equipment, and knowledge of the site status (e.g., available space at site), which adds to the long time for selecting a site. However, the scalability of fuel cell systems is a positive for sites where the power needs are not well understood because the system scale can be adjusted easily once site needs are determined. Standardized training, permitting, and safety practices would also help develop this early market further. 


\section{References}

Barilo, N. 2013. "Hydrogen Safety Panel and Hydrogen Safety Knowledge Tools." DOE Hydrogen and Fuel Cells Program 2013 Annual Progress Report. Washington, DC: U.S. Department of Energy. www.hydrogen.energy.gov/pdfs/progress13/viii_9 barilo_2013.pdf.

Colbow, K. 2010. "Fuel Cells in Extended Duration Emergency Backup Power." Presented at the 2010 Fuel Cell Seminar and Exposition, San Antonio, Texas. http://fuelcellseminar.com/wp-content/uploads/dem42-1 colbow.pdf.

DOE (U.S. Department of Energy). 2014a. Highlights from U.S. Department of Energy's Fuel Cell Recovery Act Projects. Washington, DC: U.S. Department of Energy.

http://energy.gov/eere/fuelcells/downloads/highlights-us-department-energys-fuel-cell-recoveryact-projects.

_. 2014b. "Annual Merit Review and Peer Evaluation.” Washington, DC: U.S. Department of Energy. www.hydrogen.energy.gov/annual review.html.

DSIRE (Database of State Incentives for Renewables and Efficiency). 2014a. "Business Energy Investment Tax Credit (ITC)." Database of State Incentives for Renewables and Efficiency website. Raleigh, NC: North Carolina Clean Energy Technology Center. http://programs.dsireusa.org/system/program/detail/658.

_. 2014b. "Programs." Database of State Incentives for Renewables and Efficiency website. Raleigh, NC: North Carolina Clean Energy Technology Center. http://programs.dsireusa.org/system/program.

FEMA (Federal Emergency Management Agency). 2014. "FEMA MOTF Hurricane Sandy Impact Analysis." FEMA Modeling Task Force Web Map. Washington, DC: Federal Emergency Management Agency.

http://fema.maps.arcgis.com/home/webmap/viewer.html?webmap=307dd522499d4a44a33d7296 a5da5ea0.

Kenny, K. 2013. "Use of 72-Hour Hydrogen PEM Fuel Cell Systems to Support Emergency Communications." DOE Hydrogen and Fuel Cells Program 2013 Annual Progress Report. Washington, DC: U.S. Department of Energy. www.hydrogen.energy.gov/pdfs/progress13/x _ 4 kenny_2013.pdf.

Kurtz, J., G Saur, S. Sprik, S., and C. Ainscough. 2014. Backup Power Cost of Ownership Analysis and Incumbent Technology Comparison. NREL/TP-5400-60732. Golden, CO: National Renewable Energy Laboratory. www.nrel.gov/docs/fy14osti/60732.pdf.

Mahadevan, K., K. Judd, H. Stone, J. Zewatsky, A. Thomas, H. Mahy, and D. Paul. 2007. Identification and Characterization of Near-Term Direct Hydrogen Proton Exchange Membrane Fuel Cell Markets. Columbus, OH: Battelle. www1.eere.energy.gov/hydrogenandfuelcells/pdfs/pemfc_econ_2006_report_final_0407.pdf. 
Maxwell, M. 2012. "PEM Fuel Cell Systems Providing Backup Power to Commercial Cellular Towers and an Electric Utility Communications Network." Presented at the DOE Hydrogen and Fuel Cells Program 2012 Annual Merit Review and Peer Evaluation Meeting, Arlington, Virginia. www.hydrogen.energy.gov/pdfs/review12/h2ra006_maxwell_2012_p.pdf.

NREL (National Renewable Energy Laboratory). 2012. Fuel Cell Backup Power Geographical Visualization Map. NREL/FS-5600-56740. Golden, CO: National Renewable Energy

Laboratory. www.nrel.gov/docs/fy13osti/56740.pdf.

NREL. 2013a. "Early Fuel Cell Market Demonstrations." Golden, CO: National Renewable Energy Laboratory. www.nrel.gov/hydrogen/proj_fc_market_demo.html.

- 2013b. "Operation Hours and Projected Hours to 10\% Voltage Drop." CDP LAB 01, 03/25/2013. Golden, CO: National Renewable Energy Laboratory. www.nrel.gov/hydrogen/cfm/images/cdp_lab_01_durabilityhrs.jpg.

NREL. 2014. "Grid Outages and Fuel Cell Usage for Backup Power.” Golden, CO: National Renewable Energy Laboratory. http://youtu.be/Hq_5BpQM1bk.

Office of Electricity Delivery and Energy Reliability. 2014. "Electric Disturbance Events Annual Summaries (OE-417)." Washington, DC: DOE Office of Electricity Delivery and Energy Reliability. www.oe.netl.doe.gov/oe417.aspx. 


\section{Appendix A: Overview of NREL's Data Analyses}

Working in collaboration with DOE and industry project partners, NREL acts as the central data repository for the data collected from fuel cell demonstration projects, including assessments of fuel cell electric vehicles, fuel cell buses, fuel cell powered material handling equipment, stationary power, and fuel cell backup power. To protect proprietary and business-sensitive data that have been supplied by industry partners, DOE's Fuel Cell Technologies Office within the Office of Energy Efficiency and Renewable Energy established a National Fuel Cell Technology Evaluation Center (NFCTEC) at NREL to house sensitive data and enable data analysis (see Figure A-1).

Individual system, fleet, and site analysis results are aggregated into public results called composite data products (CDPs) that show the status and progress of the technology without identifying individual companies or revealing proprietary information. Prior to publication, the project's industry partners review the CDPs and provide their input and approval. CDPs enable NREL to publish in-depth analyses without identifying individual companies or their performance. These CDPs report on the progress of the technology and the deployment projects, focusing on the most significant results.

While the raw data are secured by NREL to protect commercially sensitive and proprietary information, individualized data analysis results are provided as detailed data products (DDPs) to the partners who supplied the data. These DDPs identify individual contributions to CDPs and are intended to assist companies as they refine and improve fuel cell technologies but are not made available to the public. Those interested in providing data or updates may do so via techval@nrel.gov. More information is available at www.nrel.gov/hydrogen/proj_tech_validation.html.

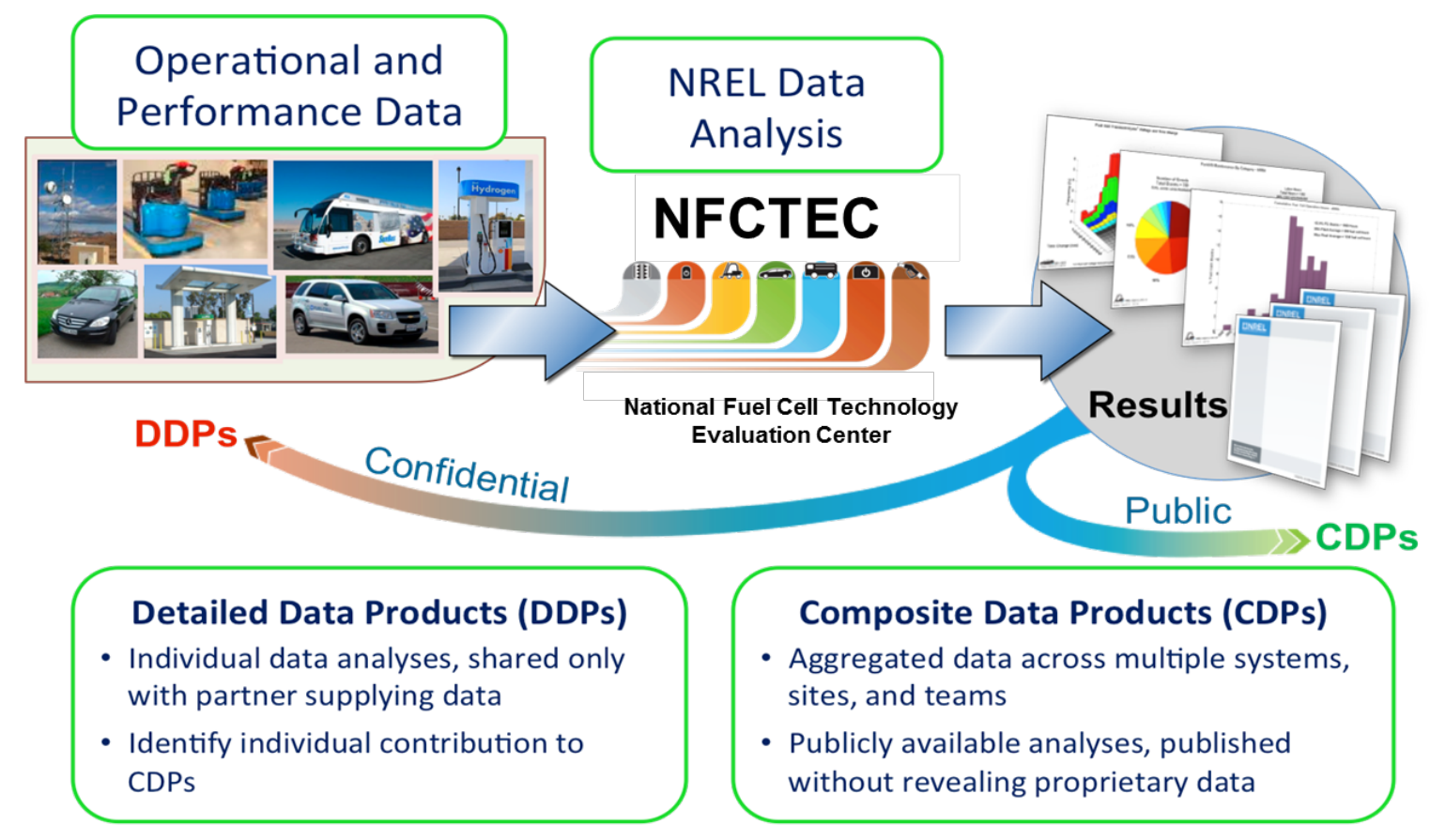

Figure A-1. NREL's aggregated data analysis using the NFCTEC 


\section{Appendix B: List of Composite Data Products}
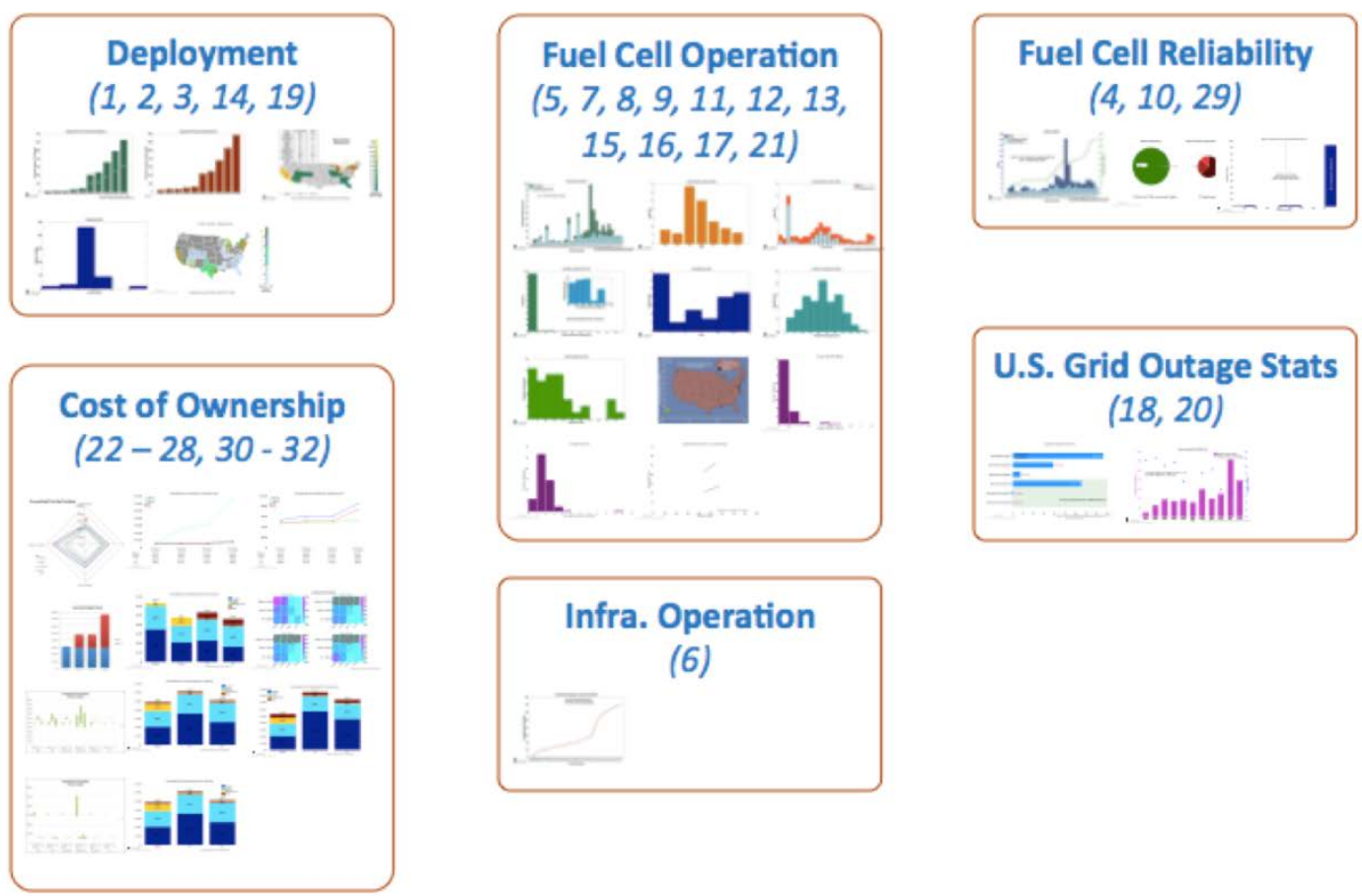

Figure B-1. Fuel cell backup power CDPs by analysis category and number 